\title{
B-cell maturation antigen targeting strategies in multiple myeloma treatment, advantages and disadvantages
}

Shirin Teymouri Nobari ${ }^{1}$, Jafar Nouri Nojadeh ${ }^{2}$ and Mehdi Talebi ${ }^{3^{*}}$

\begin{abstract}
B cell maturation antigen (BCMA), a transmembrane glycoprotein member of the tumor necrosis factor receptor superfamily 17 (TNFRSF17), highly expressed on the plasma cells of Multiple myeloma (MM) patients, as well as the normal population. BCMA is used as a biomarker for MM. Two members of the TNF superfamily proteins, including B-cell activating factor (BAFF) and A proliferation-inducing ligand (APRIL), are closely related to BCMA and play an important role in plasma cell survival and progression of MM. Despite the maximum specificity of the monoclonal antibody technologies, introducing the tumor-specific antigen(s) is not applicable for all malignancies, such as MM that there plenty of relatively specific antigens such as GPCR5D, MUC1, SLAMF7 and etc., but higher expression of BCMA on these cells in comparison with normal ones can be regarded as a relatively exclusive marker. Currently, different monoclonal antibody (mAb) technologies applied in anti-MM therapies such as daratuzumab, SAR650984, GSK2857916, and CAR-T cell therapies are some of these tools that are reviewed in the present manuscript. By the way, the structure, function, and signaling of the BCMA and related molecule(s) role in normal plasma cells and MM development, evaluated as well as the potential side effects of its targeting by different CAR-T cells generations. In conclusion, BCMA can be regarded as an ideal molecule to be targeted in immunotherapeutic methods, regarding lower potential systemic and local side effects.
\end{abstract}

Keywords: B-cell maturation antigen, CAR-T cells, Multiple myeloma, Therapy

\section{Introduction}

Multiple myeloma (MM) is known as a malignancy of plasma cells (PCs) located in the bone marrow, that leads to excess production of abnormal immunoglobulins and bone destruction. MM is a primary malignancy of the BM PCs initiated by the transformation of memory B cells (CD19+, CD 27+, CD 38+, CD45-, and CD138-) [1]. In recent decades, many therapy strategies have been developed based on monoclonal antibodies (mAb) (such as daratumumab or elotuzumab), proteasome inhibitors

\footnotetext{
${ }^{*}$ Correspondence: talebime@tbzmed.ac.ir

${ }^{3}$ Department of Applied Cells Sciences, Faculty of Advanced Medical Sciences, Tabriz University of Medical Sciences, Tabriz, Iran

Full list of author information is available at the end of the article
}

and immunomodulatory drugs. However, MM remains an incurable disease yet. Its severity and clinical and/ or laboratory stages manifestations vary from a premalignant precursor, monoclonal gammopathy of undetermined significance (MGUS), to smoldering MM, and active MM finally [2]. The progression of multiple myeloma to invasive disease is due to genetic mutations and chromosomal abnormalities. Many of these alterations are associated with changes in metabolism, apoptosis, cell growth, and the epigenetics of MM cells [3]. MM cells are in close contact with BM accessory cells that eventually lead to the spread, survival, and escape of the immune system. These bone marrow stroma cells include endothelial cells, osteoclasts and osteoblasts, BM macrophages, regulatory $\mathrm{T}$-cells $\left(\mathrm{T}_{\mathrm{reg}} \mathrm{s}\right)$, plasmacytoid DCs

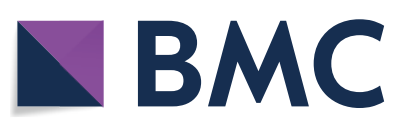

(c) The Author(s) 2022. Open Access This article is licensed under a Creative Commons Attribution 4.0 International License, which permits use, sharing, adaptation, distribution and reproduction in any medium or format, as long as you give appropriate credit to the original author(s) and the source, provide a link to the Creative Commons licence, and indicate if changes were made. The images or other third party material in this article are included in the article's Creative Commons licence, unless indicated otherwise in a credit line to the material. If material is not included in the article's Creative Commons licence and your intended use is not permitted by statutory regulation or exceeds the permitted use, you will need to obtain permission directly from the copyright holder. To view a copy of this licence, visit http://creativecommons.org/licenses/by/4.0/. The Creative Commons Public Domain Dedication waiver (http://creativeco mmons.org/publicdomain/zero/1.0/) applies to the data made available in this article, unless otherwise stated in a credit line to the data. 
(pDCs), dendritic cells, mesenchymal cells, and myeloidderived suppressor cells. These cells support MM cells by producing a wide variety of cytokines, antiapoptotic and growth factors, for example, macrophage inflammatory protein- $1 \alpha$ (MIP- $1 \alpha)$, tumor growth factor $\beta$ (TGF $\beta$ ), B-cell activation factor (BAFF), A proliferation-inducing ligand (APRIL), and most importantly interleukin-6 (IL6) [2] (Fig. 1). Important signaling pathways that are activated include STAT3, NF-кB, ERK1/2, AKT/PI3K, and play an important role in disease progression. New therapies directly target the growth and survival of MM cells which are necessary strategies in high-risk relapsed and refractory (RR) MMs [4]. B cell maturation antigen (BCMA) is the target of the choice antigen used in antiMM immunotherapy. BCMA is a non-tyrosine kinase receptor surface glycoprotein that is widely expressed on malignant plasma cells and most MM cell lines as well [5]. BCMA by its ligand, APRIL, increases survival and long-lived plasma cells that contribute to MM development. It is closely related to the BAFF receptor (BAFF-R), that highly expresses on MM cells. The NF- $\mathrm{B} B$ pathway is mainly activated by binding APRIL or BAFF to BCMA and to protecting $\mathrm{MM}$ cells by activating anti-apoptotic proteins like; BCL-XL, BCL-2, MCL-1 [6-8]. TNF receptor activates $\mathrm{BAFF}$ on transcription, proliferation, survival, and differentiation of MM cells by activating NF-kB factor [9]. Chimeric antigen receptor (CAR) $\mathrm{T}$ or NK cells, GSK2857916 an antibody-drug conjugate, and bispecific antibodies are considered as several specific treatments for MM [10]. Through genetic engineering, $\mathrm{T}$ cells can detect cells that express BCMA. BCMAspecific CARs transfected T-cells, called anti-BCMACAR-T-cells demonstrated specific MM cells killing activity in vitro [11, 12]. Julia Bluhm et. al. [13] reported that BCMA can be an interesting target for CAR T-cells therapy approaches. Conventional treatments with monoclonal antibodies have lower side effects and costs than CAR-T cell but depend on the high concentration of BCMA expression in cells. Antibody-drug conjugates (ADCs) are strategies to increase mAb therapy. In this

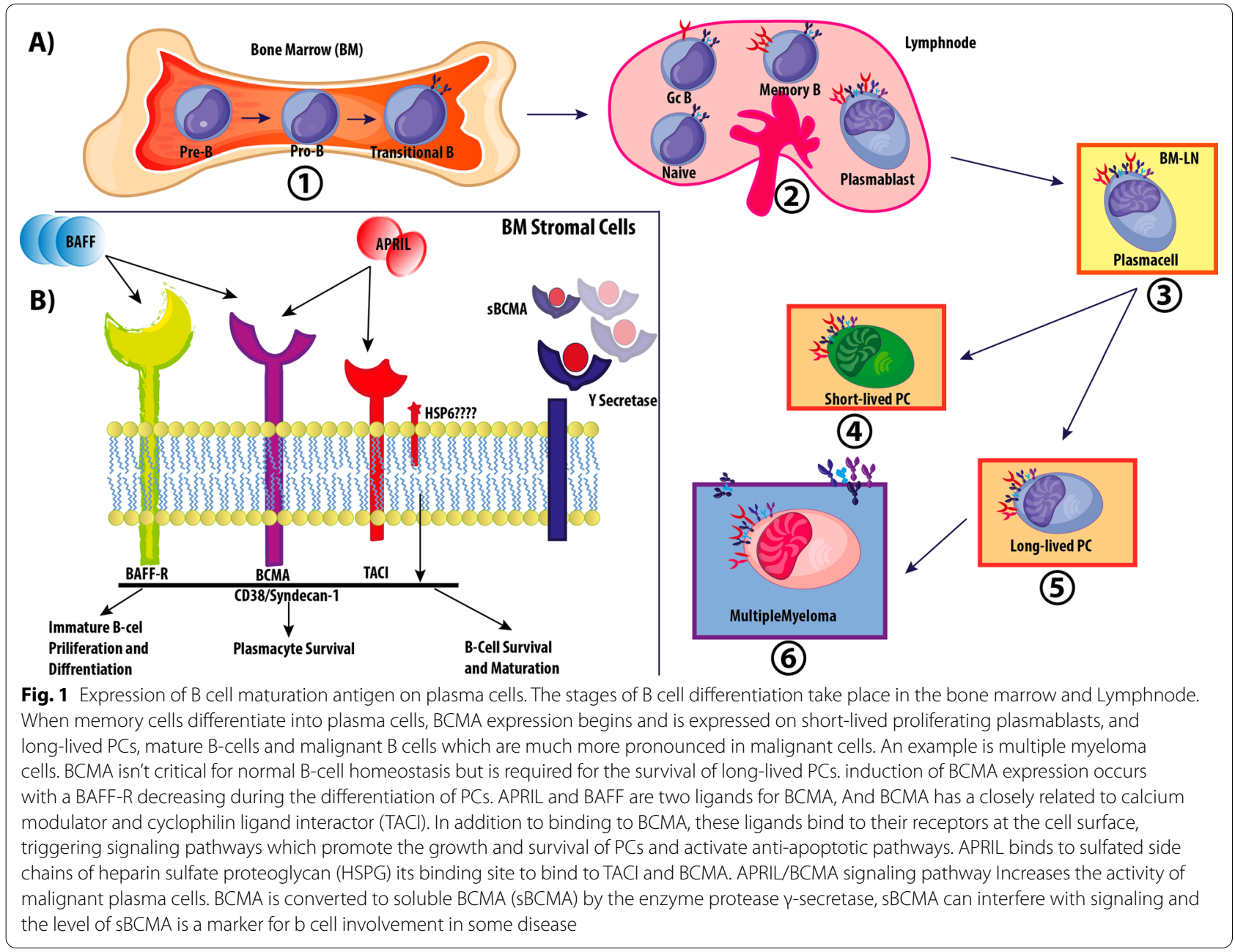


method, cytotoxic payload is directed to tumor cells that escaped from the immune system and bispecific mAbs bind T or NK cells to tumor cells, activating effective cells and lysing malignant cells [14].

Finding the Tumor-Specific Antigens as a unique marker for targeting tumor cells other than normal ones is the challenging part of any immunotherapy approaches, as in CAR-T cell therapy manipulating technics. There are some known relatively specific markers for tumoral plasma cells to distinguish from normal ones, such as CD38, CD138, G-protein Coupled Receptor 5D (GPRC5D) [15, 16] SLAMF7 (CD319), MUC1 (engineered CAR T Cells Targeting the Cancer-Associated Tn-Glycoform of the Membrane Mucin MUC1 Control Adenocarcinoma), as well as other non-specific markers such as CD44v6, CD56, NKG2, Lewis-X, but a higher and relatively specific expression of the BCMA on these cells, currently makes it an optimal but not ideal target in CAR-T cell therapy methods. During selecting process of the optimal immunologic target(s), Specific expression patern of the target is as important as the antigen shedding status of it, because soluble antigens participating in the mAbs neutralization or inactivates CAR T-cells, about this feature as the shedding process of BCMA is related to $\gamma$-secretase membrane enzyme function, controlling the shedding status is so easier than the other targeting options, theoretically. However, regarding the molecule expression pattern on the normal plasma cells, studying the full functional mechanisms, and local and/ or systemic side effects of the targeting solely or in combination with other antigens, is the background aimed in this review, at the same time currently introduced $\mathrm{mAb}$ based approaches reviewed because of the vicinity of the both $\mathrm{mAb}$ and CAR T-cell technologies.

\section{BCMA structure and function}

BCMA is a cell membrane type III non-tyrosine kinase receptor glycoprotein [17-19]. This protein does not have a signal peptide, its extracellular residues are rich in cysteine $[20,21]$. There are six motifs in the $\mathrm{N}$ terminal section of this receptor, which indicates that the BCMA is a member of the tumor necrosis factor receptor superfamily 17 (TNFRSF17)/CD269 [2]. TNF and TNF receptors family members are important in enhancing immune functions [22]. It is specifically expressed on plasma blasts and plasma cells (PCs) [23]. It is detected in the interfollicular region of the germinal centers but no evidence of expression in the follicular mantle zone has been reported [24]. Lack of BCMA doesn't affect the number of normal B cells but disrupts long-lived plasma cells $[24,25]$. Firstly, Tsapis et. al. described the BCMA gene through molecular analysis of $\mathrm{t}(4 ; 16)(\mathrm{q} 26 ; \mathrm{p} 13) /$ IL2/TNFRSF17 in human intestinal T-cell lymphoma
[19]. BCMA was predicted to be an integral transmembrane protein with 24 hydrophobic central amino acids region in an $\alpha$-helix structure [26], containing three exon regions separated by two introns that encode 185 amino acids peptide [18].

As mentioned, BCMA is a glycoprotein whose glycosylation is a common practice for modulating membrane proteins [27] and this process keeps the protein on the cell membrane [28]. The N-glycan site in BCMA is probably in the asparagine $(\mathrm{N})$ residue at 42 nd amino acid (N42). The N-glycosylation is important because of its role in regulating plasma cell function through ligand binding control. In addition, BCMA glycosylation, especially its sialylation, promotes cell survival $[15,25]$.

Recently, two members of the TNF superfamily proteins called B-cell activating factor (BAFF) and A proliferation-inducing ligand (APRIL), that BCMA closely interacts with, have been identified and their role in the maturation and differentiation of $B$ cells have been described [16].

BAFF (BLyS, TALL-1), a member of the tumor necrosis factors superfamily, is known to stimulate B cells [29]. This molecule, which is mainly expressed by macrophages and dendritic cells, is the survival signal for peripheral B cells $[30,31]$. In some B cell malignancies, such as myeloma and autoimmune diseases, increase BAFF expression has been shown [32, 33]. During the study of systemic lupus erythematosus (SLE), it was found that overexpression of transgenic BAFF caused autoimmune disease $[33,34]$ so that it may play a role in autoimmune disorders $[35,36]$. In many B-cell neoplasms, BAFF signaling becomes inefficient and causes tumor cells to grow and survive by creating an autocrine ring [33, 37]. BAFF also promotes tumor cells by activating NF-kB (nuclear factor kappa- B), BCL2, BCLX(L) upregulation, and downregulation of BAX [38].

BAFF binds to three specific receptors on B cells: BAFF receptor, TACI (transmembrane activator calcium modulator and cyclophilin ligand interactor), and BCMA. It binds to BCMA in normal cells to increase cell survival, proliferation, differentiation, and antibody production [30, 39]. Serum levels increasing of BAFF shown in multiple myeloma patients $[8,40]$, but the BAFF receptor is difficult to detect on malignant plasma cells [41] and so suggesting that it has less effect on the survival of multiple myeloma cells [42].

APRIL was initially detected on tumor cells; it is secreted by myeloid cells and penetrates the bone marrow during abnormal myelopoiesis in multiple myeloma. It was later shown to be able to secrete immunoglobulins and class switching involved in B cells. Multiple myeloma cell line is dependent on interleukin-6. In the absence of this interleukin, APRIL protects cells $[8,29,43]$ and 
saves them from dexamethasone-induced apoptosis [8]. APRIL binds only to BCMA and TACI [16], Binding to BCMA suppresses the immune system in the bone marrow and increases the growth of multiple myeloma cells. this physiological relationship indicates that BCMA has greater affinity and interaction with APRIL [44, 45]. APRIL promotes the survival of malignant plasma cells through heparan sulfate proteoglycans, which its roles in regulating cell adhesion, cytoskeletal re-organization, migration, and growth factor signaling have been shown [46-50]. This indicates that APRIL has a more specific role than BAFF [46]. Both BAFF and APRIL are involved in tumor cells by transmitting antitumor signals [51]. In patients with multiple myeloma, they increase compared to normal people[52]. BAFF and APRIL stimulate multiple myeloma cells through anti-apoptotic molecules such as BCL2, MCL1 [6, 29, 43].

TACI expressing on mature $B$ cells upregulates on activated B cells and plasma cells [53]. In humans, TACI (TNFRSF13B) gene mutations in humans are shown in about $10 \%$ of patients with Common Variable ImmunoDeficiency (CVID) disorder, which manifests with impaired antibody production and are more susceptible to Streptococcus pneumoniae and Hemophilus influenzae infections, as well as autoimmune diseases $[54,55]$.

\section{BCMA expression}

When BCMA was firstly cloned from human $\mathrm{T}$ cell lymphoma, noticed that its expression was associated with $B$ cell maturation and the highest level observed in the plasma cell line [19]. BCMA protein is located in the Golgi apparatus, which its expression is relatively limited to a specific cell lineage, B cells, so it a hypothesis that as the Golgi apparatus is larger and more abundant in plasma cells, it may perform as an antibody secretion facilitator [28].

BCMA expression has been tracked on differentiated PCs a well as plasma blasts. This protein is produced in memory B cells differentiating to plasma cells and is present in all PCs but not in CD34+ HSCs, naive B cells, and other normal tissue cells [16, 25, 56-58]. Blimp-1(Blymphocyte-induced maturation protein 1 ), a gene controlling the proliferation of PCs, has a positive inducer of BCMA expression [59].

Induction of BCMA expression occurs with a BAFF$\mathrm{R}$ decreasing during the differentiation of PCs $[25,60]$. $\mathrm{BCMA}$ is present on the surface of mature and malignant B lymphocytes too [19, 40, 61, 62], so its expression is not limited to normal cells and tissues [15]. BCMA membrane expression has been detected by anti-BCMA antibodies in CD138+multiple myeloma cells [21], more commonly in malignant cells than in normal PCs and other bone marrow cells [63]. This observation is confirmed by multiple gene expression profiling and immunohistochemistry [21]. In a study by Friedman et al. MM cells and even primary MM cells show a strong expression of BCMA [64]. BCMA was detected using Chromatin immunoprecipitation, which is required for the analysis of IRF4, a transcription factor for MM [65], also its expression is preserved in MM patients after treatment [66]. Regulated and widespread expression of BCMA on MM cells stimulates cell growth and suppresses the immune system in the bone marrow [5]. In the Kinner et. al. study, primary bone marrow samples were taken from eighth patients with $\mathrm{MM}$ to analyze the expression of BCMA on the surface of MM cells and myeloma progenitor cells (MPC), MPCs do not have the plasma cell phenotype and are not completely differentiated [5], they have a weaker response in patients to treatments such as stem cell transplantation and proteasome inhibiting [67]. In several hematological tissues including bone marrow, tonsils and spleen, lymphnodes, white blood cells, BCMA isoforms were detected by qPCR [40], its expression in various blood cells, and Hodgkin lymphoma was assessed by flow cytometry [68], as well as in glioblastoma [69], chronic lymphocytic leukemia [70, 71], and Raji-Burkitt's Lymphoma and primary lymphoma $[61,72]$. No expression could be detected in endothelial cells, keratinocytes, fat cells within tissues $[73,74]$ and in other blood cells including neutrophils, macrophages, and $\mathrm{T}$ cells $[75,76]$. In addition, there is another type of PCs called plasmacytoid dendritic cells (pDCs) that is involved in the survival and drug resistance of MM cells [77]. These cells have significantly lower BCMA expression than PCs [78], pDCs located in the bone marrow near MM cells to enhance their growth and survival [77], so the role of BCMA in pDCs causes further enhancement of the viability and drug resistance of MM cells [77].

A study in the UK on $70 \mathrm{MM}$ patients showed that BCMA expression was maintained through disease recurrence, extramedullary spread, and residual disease [66]. Tai et. al. showed that BCMA is expressed on the MM cells and is limited to plasma cells. The density of BCMA on the cell surface was measured using MFI (Mean Fluorescent Index) by flow cytometric analysis [63]. An enzyme called $\gamma$-secretase, a multi-subunit protease cleaves BCMA to release its soluble form called sBCMA [79]. The level of sBCMA is a marker for B cell involvement in known autoimmune diseases [80] and is more closely related to the patient's clinical condition [81]. In Systemic Lupus Erythematosus (SLE), the serum level of sBCMA is strongly associated with disease activity [82]. In a study of 209 patients on new case multiple myeloma, the level of sBCMA was significantly lower than in the control group and its significance in monoclonal gammopathy was not determined [63]. Also, in 
patients with indolent MM, the amount of sBCMA is less than active MM. In addition, the amount of this protein in MM disease is associated with clinical response, overall survival and is inversely related to the production of polyclonal antibodies in these patients [63]. In the studies of Germezi et. al. who introduced sBCMA as a biomarker that can control and predict the results of MM patients and by examining 243 patients, the level of this protein measured by ELISA method in smoldering MM and active MM was high, in addition, sBCMA levels are correlated with plasma cell ratio at biopsy, patient's clinical status, and M protein [25, 83, 84]. As a result, the study of BCMA expression could serve as a target for access to antitumor effects in MM patients [63].

\section{Role of $B C M A$ in the signaling pathways}

BCMA mainly plays an important role in B cells for their proliferation, survival and also differentiates them into plasma cells $[17,25]$. Humoral immunity status is affected by BCMA probably via increasing the survival of normal plasma blasts and PCs $[39,85]$. BCMA does not appear to be critical for overall $\mathrm{B}$ cell homeostasis as it is not presented in naïve and memory B cells, but for the survival of Long-lived PCs in the BM is necessary [25, 60]. BCMA-related factor, BAFF-R, acts as the main receptor for B cell survival. Another protein TACI plays a negative but important role in regulating $B$ cell homeostasis and autoimmunity. Continuous expression of BCMA in multiple myeloma prototypes indicates that it is a receptor for regulating prosurvival pathways [68].

APRIL and BAFF, which are ligands of the TNF family, are associated with three members of the TNFR, including TACI (CD267, TNFRSF13B) [86], BAFFR (BR3, CD268, TNFRSF17) [87, 88] and BCMA (CD269, TNFRSF13C) [19]. The structure of glycosaminoglycans, such as those found in Sindcan1 (DC138), is the independent junction of APRIL and TACI [50, 89]. Figure 1 has summarized the process.

There is a BAFF signal that is required for cell survival during differentiation, besides the BCR signal, that its downregulation results in the loss of more than $90 \%$ of mature B cells[90, 91]. As mentioned, TACI acts as a negative regulator in the maturation process of $B$ cells, yet BCMA has no role in this stage whereas its role is in the later stages of differentiation [60, 92-94]. In a study of 293 transfected cells, it was observed that increasing the BCMA expression activates the NF- $\mathrm{kB}$ signaling pathway, relating to TRAF2, TRAF5, TRAF6, IKK1, and IKK2 elements [60, 95] (Fig. 2).

\section{BAFF-R signaling pathways}

The APRIL-BAFF bonding role dominates in the next step of B-cell differentiation [96]. BAFF and its receptor play an important role in the development and survival of B cells [97]. Although BAFF does not induce cell proliferation alone, cells prepared with BAFF invitro transcribe the proteins required by the cell cycle, and BCR-induced proliferation occurs more rapidly. Cell size and protein content of the cells is positively controlled by BAFF, as well as forcing cells to glycolytic metabolism [98]. Elevated BAFF levels play a role in autoimmune diseases, so it is important to understand the supportive signaling pathways in B cell survival [97]. The NF- $\mathrm{KB}$ is the most important pathway that activating by two: the classical (Canonical) and the alternative (noncanonical) pathways, with transcription factors including NF-kB1(P50 and its precursor P105), NF-kB2(P52 and its precursor P100), RelA (P65) RelB, and c-Rel [99] (Fig. 2). The alternative pathway is the major pathway for B cell survival through BAFF-R, characterized by the presence of IKK1 and P100 phosphorylation cleaving to P52 [100]. The processed p52 heterodimerize with RelB, migrates to the nucleus, and induces transcription of anti-apoptotic genes. IKK1 is also phosphorylated by NIK [101]. In unstimulated cells, TRAF3, TRAF2, and cIAPs1/2 factors are linked together, NIK is continuously destroyed by the proteasome, These three sets(TRAF3, TRAF2, and cIAPs1/2) are a factor for NIK ubiquitination and targeting it for degradation[102, 103]. After cell stimulation, TRAF3 is exposed to BAFF-R, which causes TRAF3 self-degradation by cIAPs $1 / 2$ and TRAF2, This action leads to the stabilization of NIK and eventually causes cleavage of $\mathrm{P} 100[103,104]$. The NF- $\mathrm{kB}$ alternative pathway is activated by the CD40 receptor too, a member of the TNF family (Fig. 2).

\section{BCR signaling}

Signal transduction by the BCR on mature naive recirculating $B$ cells is achieved by the association of Ig- $\alpha / \operatorname{Ig}-\beta$ heterodimer. The classic pathway is activated by the formation of P50 and P65 dimers after BAFF-R stimulation [105]. Also, the activation of canonical NF- $\mathrm{KB}$ signaling is induced by the Carma/Bcl10/ Malt1 (CBM) complex. In $\mathrm{B}$ cells, the PI3K signaling pathway activates $\mathrm{PKC} \beta$, so phosphorylated CARMA1 increases canonical activation of NF- $\kappa B$ through the CBM complex as well as the phosphorylation of IKK2 by the TAB/TAK complex [106]. In addition, IKK1 can contribute to the canonical IKK2/Nemo pathway by giving some important survival signals $[107,108]$ and it is also important in B cells for GC formation (Fig. 2). Also, the BCR prompts p100 to facilitate BAFF-R signaling. The expression of p100 acts as an inhibitor of p50 and p65 [108]. Therefore, canonical and non-canonical NF-kB pathways have special properties that ultimately determine the tempo and specificity of gene expression [109]. 


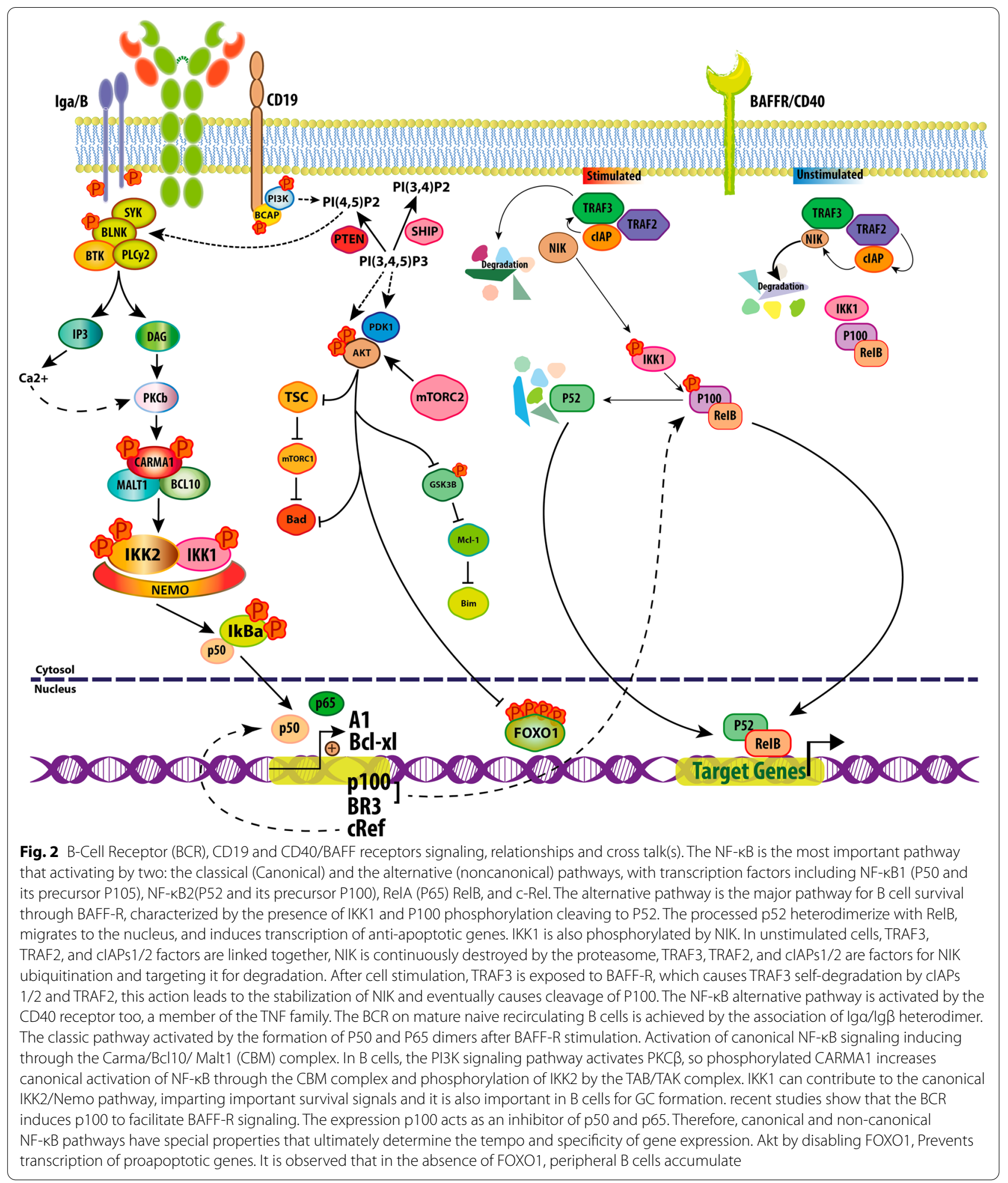

\section{PI3K pathway}

Another pathway downstream of BAFF-R is called PI3K, which plays an important role in BCR signaling and helps B cell survival. Recent studies showed that PI3K signaling induction correlates with $\mathrm{B}$ cells maturation defects improvements $[98,110,111]$. The class IA PI3Ks 
comprise of three catalytic isoforms $(\mathrm{p} 110 \alpha, \beta$, and $\delta)$ that form heterodimers with adapter subunits (p85 $\alpha$, $\mathrm{p} 55 \alpha, \mathrm{p} 50 \alpha, \mathrm{p} 85 \beta$, and $\mathrm{p} 55 \gamma$ ), whose functions are regulating enzymatic activity [112]. p110 can play its role by applying p85 with transmembrane adapter CD19 associated with cytosolic BCAP in B-cell receptor signaling. PtdIns $(3,4,5) \mathrm{P} 3$ and PtdIns(3,4)P2 are may be substrates for the phosphoinositide 3-phosphatase PTEN, which seemed like the main functional antagonist of PI3K [113]. Production of PtdIns P3 stimulates cell growth, proliferation, survival, and differentiation pathways. By Akt phosphorylation, BAFF induces PI3K activity [98] (Fig. 2). The significance of this induction is that cells in p110 deficient have difficulty responding to BAFF-induced survival [114]. In regard to the downstream effector pathways, BAFF interaction with Btk, PKC $\beta$, and Akt promotes ribosome biogenesis and enhances metabolic activity to prime $B$ cells for antigen-induced proliferation $[115,116]$. Also, BAFF increases the regulation of the pro-survival factor Mcl-1 by the Akt-dependent inactivation of GSK3 $\alpha / \beta$ [117]. Akt by disabling Foxo1 prevents transcription of proapoptotic genes. It is observed that in the absence of FOXO1, peripheral B cells accumulate [118, 119]. PI3K binds to adapter proteins CD19 and BCAP and produces PtdIns P3, which in turn employs PLC $\gamma 2$ and Btk. Btk activates PLC $\gamma 2$, increases DAG production, and enhances intracellular $\mathrm{Ca} 2+$ release which merges to activate $Р К C \beta$. РКС $\beta$ activation is critical for the canonical NF-K $\beta$ pathway.

It is possible that the activation of Mcl-1 expression is regulated primarily in a post-translational manner which needs PI3K signaling. Also, it should be noted that some of the BH3-only family members are inhibited by the PI3K family. For instance, Bad is destroyed via phosphorylation by Akt, Bim, and Puma and becomes the targets of FOXO factors $[120,121]$.

\section{CD40 receptor}

CD40 is one of the main members of the TNF family that affects B cell biology [109]. CD40 expression occurs during B cell development, in the B cell transition phase, its signals support BAFF-R expression and possibly cell survival or homeostatic proliferation $[122,123]$. The presence of CD40 on mature cells stimulates proliferation, in GC, supports B cell survival, differentiation, and isotype switching [124]. CD40 is vital for the initiating of $\mathrm{T}$ cell-dependent B cell activation and therefore plays an essential role in humoral immunity response [97, 125]. CD40 signaling is mainly activated through canonical and noncanonical NF-kB pathways, and other signaling pathways such as MAPK, PI3K, and PLCg approximately after CD40 engagement [126-128]. Stimulation of CD40 causes the uptake of TRAF proteins. In this proteins family, TRAF2, TRAF3, and TRAF6 can bind directly to the cytoplasmic tail of CD40 but are indirectly associated with TRAF1 and TRAF5 [129, 130]. TRAF6 activates TAK1 resulting in activation of the canonical NF- $\kappa B$ signaling pathway $[131,132]$. TRAF2 with MEKK1 kinase activates Jnk and P38, which is important in response to CD40 ligation [128]. TRAF2 and TRAF3 with CD40 cause NIK accumulation and consequently activate the alternative NF-kB pathway [103].

\section{APRIL signaling}

APRIL is expressed in a large number of tumors and stimulates cell growth [133]. For example, in myeloma cells, it activates the MAPK, PI3K/AKT, and NF- $\mathrm{kB}$ pathways, which leads to an up-regulation of Mcl-1 and Bcl-2 anti-apoptotic proteins [8]. Also, APRIL can bind to heparan sulfate (HS) $[49,50]$, by its lysine-rich region in the $\mathrm{N}$-terminal portion. The APRIL TNF-like free region communicates with $\mathrm{BCMA}$ and TACI receptors [46]. TACI-Fc also binds to HS chains including syndecan-1 [89]. The role of syndecan-1 in interaction with cellular matrix proteins, chemokines, growth factors, and adhesion molecules has been identified [134]. A study by Je'ro^me Moreaux et. al. [46] showed that MM cells can bind to a considerable quantity of APRIL and soluble TACI via cell surface syndecan-1 which this binding to syndecan-1 is essential for APRIL myeloma cell growth and survival. Overexpression of BCMA stimulates APRIL and activates both NF- $\mathrm{KB}$ pathways. In addition, it increases angiogenesis, metastasis factors, and the expression of growth and survival genes [5]. One study found that APRIL was associated with the expression of VEGF, its receptor, and CD138, as well as with the progression of MM [135].

Several studies show that BAFF binding to BCMA or TACI induces different signaling pathways such as NF- $\mathrm{kB}$, P38 mitogen-activated kinase for BCMA [95], NF- $\kappa B$ nuclear translocation, and Jun-N-terminal kinases (JNKs) phosphorylation for TACI [136]. Also, previous studies had shown that continuous expression of BCMA in T293 cells, activates pathways including mitogen-activated protein kinase (MAPK), especially JNK, P38 kinase, NF- $\mathrm{kB}$, and Elk-1 without stimulation of BAFF or APRIL [95]. Recent findings suggest that in MM, functional mutations occur in both canonical and non-canonical NF- $\mathrm{kB}$. These mutations cause the activation of a variety of molecules such as NFKB1, NFKB2, NIK, CD40, and TACI, and inactivation of TRAF2, TRAF3, cIAP1/cIAP2 as well. Inactivation of TRAF3 represents one of the most common mutations in MM $[137,138]$ which leads to irregularity and amplification of both NF- $\mathrm{kB}$ pathways through the continuous presence of NIK. In some cases, 
NIK expression is necessary for the proliferation and spread of MM [139].

\section{Therapy}

$\mathrm{MM}$ is the second most common hematopoietic malignancy in which malignant neoplasms of plasma cells accumulate in the bone marrow [140, 141]. This malignancy is caused by changes in memory cells (CD19+, CD $27+, \mathrm{CD} 38+, \mathrm{CD} 45-$, and CD138-) [1], causing the development of osteolytic bone lesions and excessive production of monoclonal immunoglobulins in the blood and urine [140, 142]. MM arises from a precursor malignant disorder called monoclonal gammopathy of unknown significance (MGUS) and then progresses to smoldering $\mathrm{MM}$ (SMM), then active $\mathrm{MM}$, which can eventually lead to PC leukemia [143, 144]. BCMA expression gradually increases from the MGUS stage to more advanced stages of multiple myeloma, including SMM and active MM [21]. In recent decades, various therapies have been used as mAbs such as proteasome inhibitors (PI) (e.g., Bortezomib), immunomodulatory drugs (IMiDs), (e.g., lenalidomide, daratumumab and elotuzumab) [145]. The use of PI and IMiDs combinations improves the response, in addition to increasing the overall survival in recurrent MM patients. The mAbs, which are the immunotherapeutic approaches, also improves the outcome of the disease, but since drugresistant clones are always emerging, the disease remains incurable for most patients, so continuous researches for new treatments are necessary [146-148]. These methods resulted in a better response and prolonged survival, that have been summarized in Table 1 .

\section{Targeting BCMA with $\mathrm{mAb}$ in MM}

The main function of the mAbs is to block growth factors signal transduction, cause growth arrest and apoptosis, or stimulation of deletion of mAb-coated target cells by activation of the host immune system by various $\mathrm{Fc \gamma}$ receptors $(\mathrm{Fc} \gamma \mathrm{R})$ expressed on the effector cells, calling Antibody-dependent Cell Cytotoxicity (ADCC) strategies [17]. Treatment with mAbs has a longer half-life than other anti-MM drugs in ongoing and completed clinical trials combining with lenalidomide/len and dexamethasone/dex with elotuzumab (elo) targeting CS1 (SLAMF7) [149], furthermore, daratuzumab (Dara) and SAR650984 (SAR) targeting CD38 $[147,150]$. It should be noted that Dara and SAR exhibit clinical activity as monotherapy but, CS1 and CD38 are expressed in other hematopoietic cells that disrupt mAb utilization. IgG therapy helps to improve $\mathrm{mAb}$ function and is also used by antibody-drug conjugates (ADCs) to trap malfunctioning immune cells, and because MM patients have a recurrent immune system disorder, ADCs are needed to target specific antigens, directly and indirectly, to eliminate MM cells [17]. ADCs are one of the fastest-acting anticancer drugs whose function is to detect specific antigens on tumor cells, attach them, and then absorb a cytotoxic chemical (payload) along with their cargo to kill tumor cells [2]. Toxic consignments associated with ADCs include monomethyl auristatin $\mathrm{F}$ (MMAF), tubulin polymerization inhibitor, pyrrolobenzodiazepine (PBD), or the RNA polymerase II inhibitor, $\alpha$-amanitin, applying a cleavable or non-cleavable linker $[10,78,151]$. Recently, an ADC was developed to target BCMA to kill MM cells with fewer side effects [78].

\section{J6M0-mcMMAF (GSK2857916)}

J6M0 is a humanized anti-BCMA that competes with APRIL and BAFF for BCMA binding [17]. J6M0 is a mAb and IgG1 whose afucosylated state can bind to all MM cell lines due to its tendency to BCMA [78]. J6M0 has a stronger binding capacity to CD138 + cells than pDC cells, indicating an association between BCMA mRNA and its protein expression on cells. Because J6M0 with normal FC or afucosylation cannot directly lead to cell death, it is converted to J6M0 ADCs with the anticancer drug auristatin. J6M0 was linked to either valine-citrulline (vc; protease cleavable linker)-monomethyl auristatin E (MMAE) or maleimidocaproyl (mc; non-cleavable)monomethyl auristatin F (MMAF) which uses these as cargo that has higher stability and anti-tumor function $[2,78,152]$. J6M0-mcMMAF (GSK2857916) binds more strongly to MM target cells and has no adverse negative impacts on BCMA-negative cells (NK, monocytes, PBMCs, or BMSCs) [17]. Afucosylated GSK2857916 continuously enhances antibody-dependent cellular cytotoxicity[78]. This mAb stops cell proliferation by blocking the cell cycle of G2/M and induces apoptosis by activating caspases 7, 3, and 8; moreover triggers ADCC and antibody-dependent cellular-mediated phagocytosis against patient MM cells [2]. This $\mathrm{mAb}$ was the first ADC therapy with three distinct MOAs (apoptosis, ADCC, $\mathrm{ADCP}$ ) to eradicate MM cells in the BM microenvironment more effectively [17]. Recently Oca et. al. reported the maximum accumulation of GSK2857916 on tumor site in immune-competent mice injected with EL4 lymphoma tumors expressing human BCMA (El4-hBCMA) cells [153]. During Phase 1 dose-escalation and expansion handled by Trudel et. al. (NCT02064387) showed that at maximum dose of $3.4 \mathrm{mg} / \mathrm{kg}$ once every three weeks, in $60 \%$ of the patient partial response or better achieved [154], but based on Oca et. al. work, combination with other immune-check point therapies shows much better result that monotherapy once [153]. 
Table 1 Immunotherapy approaches in anti-myeloma treatments

\begin{tabular}{|c|c|c|c|c|c|}
\hline \multirow{3}{*}{$\begin{array}{l}\text { Technology } \\
\text { Mono-clonal antibody-based } \\
\text { technologies }\end{array}$} & \multicolumn{2}{|c|}{ Targeted molecule } & \multirow{3}{*}{$\begin{array}{l}\text { Introduced drug } \\
\text { Daratumumab } \\
\text { Isatoximab }\end{array}$} & \multirow{2}{*}{$\begin{array}{l}\text { Mechanism of action } \\
A D C C, A D C P, C D C\end{array}$} & \multirow{2}{*}{$\frac{\text { References }}{[62]}$} \\
\hline & Anti-CD38 & & & & \\
\hline & & & & ADCC, ADCP, CDC, Pro-apoptosis & {$[62]$} \\
\hline & Anti-SLAMF7 & & Elotuzumab & $\begin{array}{l}\text { ADCC via NK cell activation } \\
\text { through EAT- } 2 \text { and CD16 }\end{array}$ & [93] \\
\hline & \multirow[t]{4}{*}{$\begin{array}{l}\text { Antibody- } \\
\text { drug conju- } \\
\text { gates (ADCs) }\end{array}$} & Anti-BCMA & $\begin{array}{l}\text { Belantamab mafodotin (GSK- } \\
\text { 2857916) }\end{array}$ & $\begin{array}{l}\text { Humanized anti-BCMA IgG1 } \\
\text { MoA conjugated to monomethyl } \\
\text { auristatin F (MMAF) }\end{array}$ & {$[36,37]$} \\
\hline & & Anti-CD138 & Indatuximab ravtansine & $\begin{array}{l}\text { Targeting CD138, linked with } \\
\text { maytansinoid cytotoxic agent }\end{array}$ & {$[38]$} \\
\hline & & Anti-CD56 & Lorvotuzumab-mertansine & $\begin{array}{l}\text { Targeting CD56, linked to a } \\
\text { microtubule inhibitor (MD1) }\end{array}$ & {$[40]$} \\
\hline & & Anti-CD74 & $\begin{array}{l}\text { Milatuzumab } \\
\text { doxorubicin }\end{array}$ & $\begin{array}{l}\text { Targeting the CD74 linked to } \\
\text { doxorubicin }\end{array}$ & {$[8]$} \\
\hline & \multirow{8}{*}{$\begin{array}{l}\text { Bispecific } \\
\text { monoclonal } \\
\text { antibodies (Bs } \\
\text { mAbs) }\end{array}$} & CD19/CD3 & Blinatumomab & $\begin{array}{l}\text { Cytotoxicity induction by accu- } \\
\text { mulating T-cells to CD } 19+\text { cells }\end{array}$ & {$[106]$} \\
\hline & & BCMA/CD3 & AMG-420 & $\begin{array}{l}\text { Cytotoxicity induction by accu- } \\
\text { mulating T-cells to BCMA + cells }\end{array}$ & [104] \\
\hline & & BCMA/CD3 & AMG-701 & $\begin{array}{l}\text { Cytotoxicity induction by accu- } \\
\text { mulating T-cells to BCMA + cells } \\
\text { with extended serum half-life in } \\
\text { compared with AMG-420 }\end{array}$ & {$[108]$} \\
\hline & & $\mathrm{BCMA} / \mathrm{CD} 3$ & teclistamab (JNJ-64007957) & $\begin{array}{l}\text { Direct Cytotoxicity induction } \\
\text { by accumulating T-cells to } \\
\text { BCMA + cells }\end{array}$ & [110] \\
\hline & & CD38/CD3 & GBR-1342 & $\begin{array}{l}\text { Direct Cytotoxicity induction } \\
\text { by accumulating T-cells to } \\
\text { CD38 + cells }\end{array}$ & [98] \\
\hline & & CD38/CD3 & AMG-424 & $\begin{array}{l}\text { Direct Cytotoxicity induction } \\
\text { by accumulating T-cells to } \\
\text { CD38+ cells }\end{array}$ & [104] \\
\hline & & FcRH5-CD3 & Cevostamab-BFCR4350A & $\begin{array}{l}\text { Direct Cytotoxicity induction by } \\
\text { accumulating T-cells to FcRH5 } \\
\text { expressing cells }\end{array}$ & [112] \\
\hline & & GPRC5D-CD3 & talquetamab-JNJ-64407564 & $\begin{array}{l}\text { Direct Cytotoxicity induction by } \\
\text { accumulating T-cells to GPRC5D } \\
\text { presenting cells }\end{array}$ & [113] \\
\hline
\end{tabular}

Antibody-dependent cellular toxicity (ADCC), complement-dependent toxicity (CDC), antibody-dependent cellular phagocytosis (ADCP), Signaling lymphocytic molecule F7 (SLAMF7), B-Cell Maturation Antigen (BCMA), Fc Receptor H5 (FcH5), G-protein Receptor Coupled 5D (GPRC5D)

\section{Chimeric antigen receptor T-cells}

More recently, genetic therapy has been used in cell therapy approaches to manipulate $\mathrm{T}$ cell receptor genes to bind and kill tumor antigens [155]. Scientists have been introduced genetic engineering methods to produce chimeric antigen receptors (CARs) [156]. CARs are hybrid receptors for the antigen that is part of the antibody and part of the TCR and has an extracellular antigen-binding portion and an intracellular signaling domain [157]. The single-chain variable fragment $(\mathrm{scFv})$ is derived from a tumor-specific antibody [158]. In mAb, the part that detects the antigen is integrated with CAR, which accompanies $\mathrm{CD} 3 \zeta$ and a co-stimulatory molecule (such as intracellular activating domains of CD28 or 4-1BB) [159]. To achieve the final genetic construct for the CAR, a hinge and a transmembrane domain (TM), commonly from CD8 + cells or immunoglobulin bridge of the extracellular $\mathrm{scFv}$ and intracellular $\mathrm{CD} 3 \zeta$ immunoreceptor tyrosine-based activation motif (ITAM) domains can be added to constructs [160] (Fig. 3).

The first generation of in vitro CARs possessed an intracellular signaling domain and consist only of $\mathrm{CD} 3 \zeta$ to protect $\mathrm{T}$-cell activation and target killing but, these CAR $\mathrm{T}$ cells had very limited persistence and antitumor efficacy in vivo. As a result, second-generation CARs were replaced to improve T-cell performance. TCR is for the detection of foreign peptide antigens that contain 8-12 amino acids [161], therefore, it may react with peptides that have similar sequences. Due to this, $\mathrm{T}$ cells need at least two signals to be fully activated. The first signal is provided by TCR and the second signal, or 


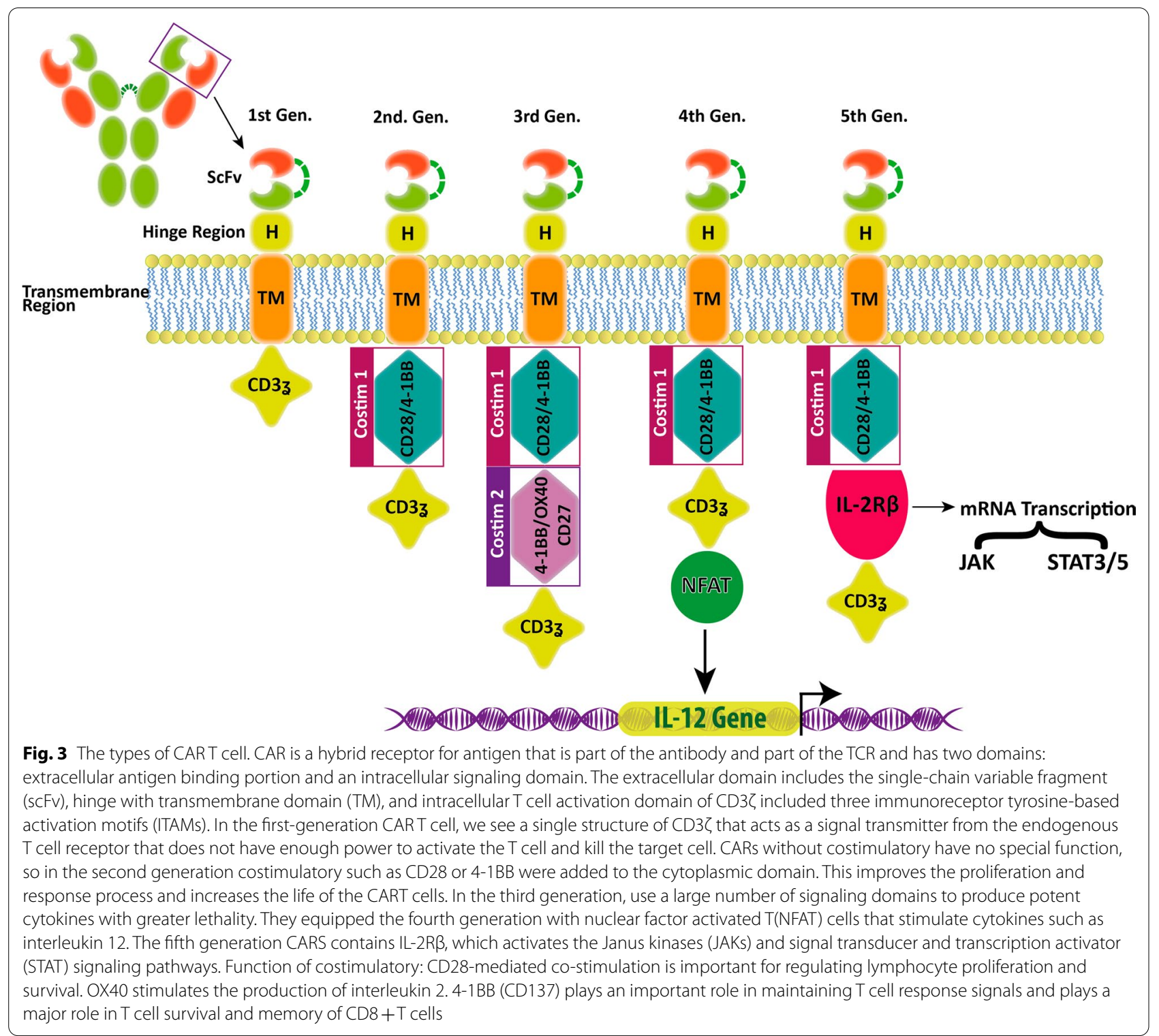

co-stimulation, is mediated through ligation of CD28 by $\mathrm{CD} 80$ or CD86, which are normally expressed on antigen-presenting cells (APC). CD80 and CD86 promote both signals and fully support T-cell activation, target killing, and long-term persistence. Therefore, $\mathrm{T}$-cell activation fails when a $\mathrm{T}$ cell is exposed to a normal peptide on a normal cell $[161,162]$. The scientists replaced the two-signal model of $\mathrm{T}$-cell activation via modifying CARs to insert a CD28 costimulatory domain in tandem with CD3 $\zeta$ ITAM domains $[163,164]$. These second-generation CARs, their most important function, cause T-cell persistence and the elimination of effective tumors in vivo [165-167]. Second-generation CAR T cells have been proved to mediate strong anti-leukemia responses in clinical trials. Also, there is a third-generation CAR that includes CD28 and OX40 co-stimulation which stimulates the superior survival of CCR7 (-) $\mathrm{T}$ cells [164]. This CAR has less stimulation than IL-10 secretion compared to a second-generation CAR [168]. Fourth-generation CAR T cells, also commonly referred to as "TRUCK" $\mathrm{T}$ cells are produced to incorporate a third stimulatory signal [169]. They contain a nuclear factor of activated T cells (NFAT) domain, which induces a large number of cytokines (e.g., IL-12). This generation is equipped with immune-stimulating cytokines to improve the persistence of CAR T cells in a tumor environment that suppresses the immune system [170]. In addition, transgenic cytokine expression such as IL-12 
can stimulate bystander $\mathrm{T}$ cells to kill antigen-negative cancer cells [169]. The fifth generation of CARs which have a fragment of the IL-2 $\beta$ (IL-2R $\beta$ ) receptor instead of the OX-40 / CD27 is being tested. Part IL-2R $\beta$ induces the producing of Janus kinases (JAKs) and signal transducer and transcription activator (STAT) -3/5 [171, 172]. The problem with this new method is that, first, to detect tumor antigen by $\mathrm{T}$ cells, it is necessary to supply that antigen by antigen-presenting cells (APC), which is not possible in tumor cells. Secondly, T cells only detect tumor peptide antigens and are unable to detect antigens of polysaccharides, lipids, etc. that are present on the surface of tumor cells. Of the advantages of this method are, firstly, it is not necessary to present antigen by HLA molecules on the surface of APCs to detect tumor antigen. Second, since the binding site for CAR antigens is derived from antibodies, tumor cells antigens that reduce their HLA molecules to escape the immune system on their surface are also identified by CAR T-Cells [173].

\section{Treatment of multiple myeloma with CAR-T cells}

The BCMA antigen is common and variable in all MM, and its expression is 25 to $100 \%$ in malignant plasma cells. A set of completely human BCMA-binding scFVs has been introduced by $\mathrm{Bu}$ et al. and has shown that this BCMA-specific antigen is commonly recurrent and resistant to treatment in phase I patients with multiple myeloma [65]. These chimeric receptors are transduced into the autologous $\mathrm{T}$ cell taken from the patient, by a retroviral or lentiviral vector or, more recently, by the Crisper/CAS9 method (for targeted placement within the genome and to prevent $\mathrm{T}$ cell tumor). And thereafter, new chimeric receptors are expressed on the cell surface. These $\mathrm{T}$ cells that express the chimeric receptors are called CAR T-Cells [156]. CAR T cells have high affinity and specificity to tumor cells as well as high cytotoxicity potential and proliferation [174]. In multiple myeloma, BCMA is the target antigen of choice commonly used in clinical trials of CAR-T cells [175, 176]. CAR T cells are also effective in treating acute and chronic leukemia and B lymphoma cells, where CD19 antigen is widely expressed. In MM, it has recently been reported that targeting activated integrin $\beta 7$ can selectively eradicate MM cells including CD19+clonotypic B cells [176-178]. Recently, a cancer-specific glycoepitope called the Muc1 protein (Tn-Muc1) was shown as a suitable target for CAR T cells against a variety of cancers [179]. Therefore, to find mAbs that bind to MM cells, an antibody called MMG49 was identified, which binds to the integrin $\beta 7$ protein, which, of course, binds only to the active integrin $\beta 7$, thus MMG49 can play as a therapeutic target for removing MM clones [180]. Also, anti-MM CAR T cell therapy targeting BCMA has been tested in phase I clinical trials, and promising results were recently obtained from NCI's group [179, 181]. In a clinical trial conducted by Ji Xu et al. in 2019, targeting CAR against BCMA antigen in 17 patients with multiple myeloma (RRMM) after lymphatic chemotherapy has shown promising results and the overall response rate was $88.2 \%$ [182]. Besides relatively higher efficiency of the method, some limitation of CAR-T cell therapy needs to be overcome, basically therapeutic resistance grossly as result of tumor heterogeneity and antigen escape, and toxicity mostly because of cytokine releasing syndrome (CRS), and neurotoxicity mediated by pro-inflammatory cytokines following manipulated T-cells activation are most common disadvantages of the methods. Currently more than 100 clinical trials submitted for multiple myeloma targeting, that about 9 studies ended or nearly ending by results.

\section{Targeting membrane molecules other than BCMA}

During conventional diagnosing protocols immunophenotyping studies of CD38/CD138 expression on suspected cells is the one of the key features for differentiating MM form other plasma cells dyscrasies or proliferations. So, it seems rational to search anti-CD38 and anti-CD138 as relatively specific tools targeting MM cells. CD38 expression level is constant during the disease stages but CD138 expression elevates during refractory and progressive stages [30-33]. Thus, these antigens seem are specific for MM but they express on other tissues, for instance CD138 express on normal tissues of hepatocytes, gastrointestinal goblet and columnar cells and squamous epithelium, at the same time, CD38 expresses on hematopoietic cells, Purkinje cells and lung smooth muscle cells. SLAM family member protein 7 (SLAMF7) expressing on normal T-cells, B-cells and NKcells that targeting with $\mathrm{mAb}$ like elotuzumab, showed lysing of these SLAMF7+ normal cells too. G-protein coupled receptor 5D (GPRCP5D) expressing on the myeloma cells at high levels, so it can be regarded as a potent target in anti-myeloma immunotherapy strategies, but its expression on the normal plasma cells or mature B-cells in lower levels, as well as hair follicles questionable its specificity. Mucin 1 (MUC1) expressing aberrantly on MM cells, its intracellular domain interacts with $\beta$-catenin and serves as substrate for glycogen synthesis kinase $3 \beta$ (GSK3 $\beta$ ) that blocks $\beta$-catenin degradation, and so increasing the cells growth and proliferation by WNT/ $\beta$-catenin. The MUC1 expression can be seen in solid tumors such as breast and colon carcinoma as well as numerous normal tissues such as, respiratory system, gastro-intestinal tract, kidney and urinary tract, female reproductive tissue and etc. that make it concerning its 
usefulness as specific multiple myeloma marker, despite its higher expression levels on MM cells.

\section{Conclusion}

During choosing the most appropriate surface markers as specific tumor antigen, there are some key properties that should be taken account such as specificity to tumor cells not normal ones, higher and constant expression of the antigen and the shedding status of the antigen should be regarded. Among the variety of surface antigens that prone to consider as specific markers BCMA seem to more potent to be targeted but more shedding and growing BCMA-negatvie MM cells, that can cause escaping the tumor cells from immunotherapy strategies, should be considered and looking after a method that maximizing the targeting effectiveness from the beginning of immune cell therapy technologies is essential. So the maximum effectiveness of the CAR T-cell and other immunotherapeutic approaches is existing and expressing Cancer-Specific Antigen of tumor cell that differentiates these cells from normal ones in the same tissue, but in some cancers, there is no known cancer-specific antigens have been defined so, the most recent advances in CAR receptor designing by regarding "AND", "OR", "NOT" conditional functions, let the researchers produce more cancer-specific CAR T-Cells especially in the situations that there is no known cancer-specific antigen have been introduced.

\section{Acknowledgements}

Greatly thanks to Tabriz University of Medical Sciences, Tabriz, Iran for preparing the environment for doing our research.

\begin{abstract}
Authors' contributions
During research and preparing the manuscript STN performed the primitive researches, study, classified and noted the available articles, prepared the primitive manuscripts and MT and JNN participated in the general idea of the review, preparing the Figures and final editing and submitting the manuscript. All authors read and approved the final manuscript.
\end{abstract}

\section{Funding}

This research did not receive any specific grant from funding agencies in the public, commercial, or not-for-profit sectors.

\section{Availability of data and materials}

Not applicable.

\section{Declarations}

Ethics approval and consent to participate

Not applicable.

\section{Consent for publication}

Not applicable.

\section{Competing interests}

The authors declare that they have no competing interests.

\section{Author details}

${ }^{1}$ Department of Medical Biochemistry, Faculty of Medicine, Urmia University of Medical Sciences, Urmia, Iran. ${ }^{2}$ Department of Medical Genetics, Faculty of Medicine, Tabriz University of Medical Sciences, Tabriz, Iran. ${ }^{3}$ Department of Applied Cells Sciences, Faculty of Advanced Medical Sciences, Tabriz University of Medical Sciences, Tabriz, Iran.

Received: 26 November 2021 Accepted: 29 January 2022

Published online: 10 February 2022

References

1. Mayani H. Hematopoietic and microenvironment alterations in bone marrow from patients with multiple myeloma. Leuk Res. 2013;37:228-9.

2. Cho SF, Anderson KC, Tai YT. Targeting B cell maturation antigen (BCMA) in multiple myeloma: potential uses of BCMA-based immunotherapy. Front Immunol. 1821;2018:9.

3. Nikesitch $\mathrm{N}$, Ling SC. Molecular mechanisms in multiple myeloma drug resistance. J Clin Pathol. 2016;69:97-101.

4. Tai YT, Anderson KC. B cell maturation antigen (BCMA)-based immunotherapy for multiple myeloma. Expert Opin Biol Ther. 2019;19:1143-56.

5. Tai YT, Acharya C, An G, Moschetta M, Zhong MY, Feng X, Cea M, Cagnetta A, Wen K, van Eenennaam $\mathrm{H}$, et al. APRIL and BCMA promote human multiple myeloma growth and immunosuppression in the bone marrow microenvironment. Blood. 2016;127:3225-36.

6. Neri P, Kumar S, Fulciniti MT, Vallet S, Chhetri S, Mukherjee S, Tai Y, Chauhan D, Tassone P, Venuta S, et al. Neutralizing B-cell activating factor antibody improves survival and inhibits osteoclastogenesis in a severe combined immunodeficient human multiple myeloma model. Clin Cancer Res. 2007;13:5903-9.

7. Shen X, Guo Y, Qi J, Shi W, Wu X, Ju S. Binding of B-cell maturation antigen to B-cell activating factor induces survival of multiple myeloma cells by activating Akt and JNK signaling pathways. Cell Biochem Funct. 2016;34:104-10.

8. Moreaux J, Legouffe $E$, Jourdan $E$, Quittet $P$, Rème $T$, Lugagne $C$, Moine P, Rossi JF, Klein B, Tarte K. BAFF and APRIL protect myeloma cells from apoptosis induced by interleukin 6 deprivation and dexamethasone. Blood. 2004;103:3148-57.

9. Demchenko YN, KuehI WM. A critical role for the NFkB pathway in multiple myeloma. Oncotarget. 2010;1:59-68.

10. Trudel S, Lendvai N, Popat R, Voorhees PM, Reeves B, Libby EN, Richardson PG, Anderson LD Jr, Sutherland HJ, Yong K, et al. Targeting B-cell maturation antigen with GSK2857916 antibody-drug conjugate in relapsed or refractory multiple myeloma (BMA117159): a dose escalation and expansion phase 1 trial. Lancet Oncol. 2018;19:1641-53.

11. Liu J, Zhong JF, Zhang X, Zhang C. Allogeneic CD19-CAR-T cell infusion after allogeneic hematopoietic stem cell transplantation in B cell malignancies. J Hematol Oncol. 2017;10:35-35.

12. Sanchez E, Smith EJ, Yashar MA, Patil S, Li M, Porter AL, Tanenbaum EJ, Schlossberg RE, Soof CM, Hekmati T, et al. The Role of B-Cell Maturation Antigen in the Biology and Management of, and as a Potential Therapeutic Target in Multiple Myeloma. Target Oncol. 2018;13:39-47.

13. Bluhm J, Kieback E, Marino SF, Oden F, Westermann J, Chmielewski M, Abken H, Uckert W, Höpken UE, Rehm A. CAR T cells with enhanced sensitivity to $B$ cell maturation antigen for the targeting of B cell non-Hodgkin's lymphoma and multiple myeloma. Mol Ther. 2018;26:1906-20.

14. Eckhert E, Hewitt R, Liedtke M. B-cell maturation antigen directed monoclonal antibody therapies for multiple myeloma. Immunotherapy. 2019;11:801-11.

15. Huang HW, Chen $\mathrm{CH}$, Lin $\mathrm{CH}$, Wong $\mathrm{CH}$, Lin Kl. B-cell maturation antigen is modified by a single $\mathrm{N}$-glycan chain that modulates ligand binding and surface retention. Proc Natl Acad Sci USA. 2013;110:10928-33.

16. Mackay F, Schneider P, Rennert P, Browning J. BAFF AND APRIL: a tutorial on B cell survival. Annu Rev Immunol. 2003;21:231-64.

17. Tai YT, Anderson KC. Targeting B-cell maturation antigen in multiple myeloma. Immunotherapy. 2015;7:1187-99.

18. Madry C, Laabi Y, Callebaut I, Roussel J, Hatzoglou A, Le Coniat M, Mornon JP, Berger R, Tsapis A. The characterization of murine BCMA gene defines it as a new member of the tumor necrosis factor receptor superfamily. Int Immunol. 1998;10:1693-702.

19. Laâbi Y, Gras MP, Carbonnel F, Brouet JC, Berger R, Larsen CJ, Tsapis A. A new gene, BCM, on chromosome 16 is fused to the interleukin 2 gene 
by a t(4;16)(q26;p13) translocation in a malignant T cell lymphoma. Embo j. 1992;11:3897-904.

20. Lonial S, Dimopoulos M, Palumbo A, White D, Grosicki S, Spicka I, Walter-Croneck A, Moreau P, Mateos MV, Magen H, et al. Elotuzumab therapy for relapsed or refractory multiple myeloma. N Engl J Med. 2015;373:621-31.

21. Carpenter RO, Evbuomwan MO, Pittaluga S, Rose JJ, Raffeld M, Yang $\mathrm{S}$, Gress RE, Hakim FT, Kochenderfer JN. B-cell maturation antigen is a promising target for adoptive T-cell therapy of multiple myeloma. Clin Cancer Res. 2013;19:2048-60.

22. Locksley RM, Killeen N, Lenardo MJ. The TNF and TNF receptor superfamilies: integrating mammalian biology. Cell. 2001;104:487-501.

23. Khare SD, Sarosi I, Xia XZ, McCabe S, Miner K, Solovyev I, Hawkins N, Kelley M, Chang D, Van G, et al. Severe B cell hyperplasia and autoimmune disease in TALL-1 transgenic mice. Proc Natl Acad Sci U S A. 2000;97:3370-5.

24. Shu $\mathrm{HB}$, Johnson $\mathrm{H}$. B cell maturation protein is a receptor for the tumor necrosis factor family member TALL-1. Proc Natl Acad Sci USA. 2000;97:9156-61.

25. O'Connor BP, Raman VS, Erickson LD, Cook WJ, Weaver LK, Ahonen C, Lin LL, Mantchev GT, Bram RJ, Noelle RJ. BCMA is essential for the survival of long-lived bone marrow plasma cells. J Exp Med. 2004;199:91-8.

26. Coquery CM, Erickson LD. Regulatory roles of the tumor necrosis factor receptor BCMA. Crit Rev Immunol. 2012;32:287-305.

27. Varki A. Biological roles of oligosaccharides: all of the theories are correct. Glycobiology. 1993;3:97-130.

28. Gras MP, Laâbi Y, Linares-Cruz G, Blondel MO, Rigaut JP, Brouet JC, Leca G, Haguenauer-Tsapis R, Tsapis A. BCMAp: an integral membrane protein in the Golgi apparatus of human mature B lymphocytes. Int Immunol. 1995;7:1093-106.

29. Tai YT, Li XF, Breitkreutz I, Song W, Neri P, Catley L, Podar K, Hideshima T, Chauhan D, Raje N, et al. Role of B-cell-activating factor in adhesion and growth of human multiple myeloma cells in the bone marrow microenvironment. Cancer Res. 2006;66:6675-82.

30. Schneider P, Mackay F, Steiner V, Hofmann K, Bodmer JL, Holler N, Ambrose C, Lawton P, Bixler S, Acha-Orbea H, et al. BAFF, a novel ligand of the tumor necrosis factor family, stimulates B cell growth. J Exp Med. 1999:189:1747-56.

31. Moore PA, Belvedere O, Orr A, Pieri K, LaFleur DW, Feng P, Soppet D, Charters M, Gentz R, Parmelee D, et al. BLyS: member of the tumor necrosis factor family and B lymphocyte stimulator. Science. 1999:285:260-3.

32. Elsawa SF, Novak AJ, Grote DM, Ziesmer SC, Witzig TE, Kyle RA, Dillon SR, Harder B, Gross JA, Ansell SM. B-lymphocyte stimulator (BLyS) stimulates immunoglobulin production and malignant B-cell growth in Waldenstrom macroglobulinemia. Blood. 2006;107:2882-8.

33. Jelinek DF, Darce JR. Human B lymphocyte malignancies: exploitation of BLyS and APRIL and their receptors. Curr Dir Autoimmun. 2005;8:266-88.

34. Gross JA, Johnston J, Mudri S, Enselman R, Dillon SR, Madden K, Xu W, Parrish-Novak J, Foster D, Lofton-Day C, et al. TACl and BCMA are receptors for a TNF homologue implicated in B-cell autoimmune disease. Nature. 2000:404:995-9.

35. Cheema GS, Roschke V, Hilbert DM, StohI W. Elevated serum B lymphocyte stimulator levels in patients with systemic immune-based rheumatic diseases. Arthritis Rheum. 2001;44:1313-9.

36. Zhang J, Roschke V, Baker KP, Wang Z, Alarcón GS, Fessler BJ, Bastian H, Kimberly RP, Zhou T. Cutting edge: a role for B lymphocyte stimulator in systemic lupus erythematosus. J Immunol. 2001;166:6-10.

37. Kern C, Cornuel JF, Billard C, Tang R, Rouillard D, Stenou V, Defrance T, Ajchenbaum-Cymbalista F, Simonin PY, Feldblum S, Kolb JP. Involvement of BAFF and APRIL in the resistance to apoptosis of B-CLL through an autocrine pathway. Blood. 2004;103:679-88.

38. He B, Chadburn A, Jou E, Schattner EJ, Knowles DM, Cerutti A. Lymphoma B cells evade apoptosis through the TNF family members BAFF/ BLyS and APRIL. J Immunol. 2004:172:3268-79.

39. Avery DT, Kalled SL, Ellyard Jl, Ambrose C, Bixler SA, Thien M, Brink R, Mackay F, Hodgkin PD, Tangye SG. BAFF selectively enhances the survival of plasmablasts generated from human memory B cells. J Clin Investig. 2003;112:286-97.
40. Novak AJ, Darce JR, Arendt BK, Harder B, Henderson K, Kindsvogel W, Gross JA, Greipp PR, Jelinek DF. Expression of BCMA, TACl, and BAFF-R in multiple myeloma: a mechanism for growth and survival. Blood. 2004;103:689-94

41. Feng X, Zhang L, Acharya C, An G, Wen K, Qiu L, Munshi NC, Tai Y-T, Anderson KC. Targeting CD38 Suppresses Induction and Function of T Regulatory Cells to Mitigate Immunosuppression in Multiple Myeloma. Clin Cancer Res. 2017;23:4290-300.

42. Dimopoulos MA, Richardson PG, Moreau P, Anderson KC. Current treatment landscape for relapsed and/or refractory multiple myeloma. Nat Rev Clin Oncol. 2015;12:42-54.

43. Moreaux J, Cremer FW, Reme T, Raab M, Mahtouk K, Kaukel P, Pantesco V, De Vos J, Jourdan E, Jauch A, et al. The level of TACl gene expression in myeloma cells is associated with a signature of microenvironment dependence versus a plasmablastic signature. Blood. 2005;106:1021-30.

44. Schneider P, Takatsuka H, Wilson A, Mackay F, Tardivel A, Lens S, Cachero TG, Finke D, Beermann F, Tschopp J. Maturation of marginal zone and follicular B cells requires B cell activating factor of the tumor necrosis factor family and is independent of B cell maturation antigen. J Exp Med. 2001;194:1691-7.

45. Patel DR, Wallweber HJ, Yin J, Shriver SK, Marsters SA, Gordon NC, Starovasnik MA, Kelley RF. Engineering an APRIL-specific B cell maturation antigen. J Biol Chem. 2004;279:16727-35.

46. Moreaux J, Sprynski AC, Dillon SR, Mahtouk K, Jourdan M, Ythier A, Moine P, Robert N, Jourdan E, Rossi JF, Klein B. APRIL and TACl interact with syndecan-1 on the surface of multiple myeloma cells to form an essential survival loop. Eur J Haematol. 2009;83:119-29.

47. Reijmers RM, Spaargaren M, Pals ST. Heparan sulfate proteoglycans in the control of B cell development and the pathogenesis of multiple myeloma. Febs j. 2013;280:2180-93.

48. Matthes T, McKee T, Dunand-Sauthier I, Manfroi B, Park S, Passweg J, Huard B. Myelopoiesis dysregulation associated to sustained APRIL production in multiple myeloma-infiltrated bone marrow. Leukemia. 2015;29:1901-8.

49. Hendriks J, Planelles L, de Jong-Odding J, Hardenberg G, Pals ST, Hahne $M$, Spaargaren M, Medema JP. Heparan sulfate proteoglycan binding promotes APRIL-induced tumor cell proliferation. Cell Death Differ. 2005;12:637-48.

50. Ingold K, Zumsteg A, Tardivel A, Huard B, Steiner QG, Cachero TG, Qiang F, Gorelik L, Kalled SL, Acha-Orbea H, et al. Identification of proteoglycans as the APRIL-specific binding partners. J Exp Med. 2005;201:1375-83.

51. Novak AJ, Bram RJ, Kay NE, Jelinek DF. Aberrant expression of B-lymphocyte stimulator by B chronic lymphocytic leukemia cells: a mechanism for survival. Blood. 2002;100:2973-9.

52. Leone P, Berardi S, Frassanito MA, Ria R, De Re V, Cicco S, Battaglia S, Ditonno P, Dammacco F, Vacca A, Racanelli V. Dendritic cells accumulate in the bone marrow of myeloma patients where they protect tumor plasma cells from CD8+ T-cell killing. Blood. 2015;126:1443-51.

53. Darce JR, Arendt BK, Wu X, Jelinek DF. Regulated expression of BAFFbinding receptors during human B cell differentiation. J Immunol. 2007:179:7276-86.

54. Castigli E, Wilson SA, Garibyan L, Rachid R, Bonilla F, Schneider L, Geha RS. TACl is mutant in common variable immunodeficiency and IgA deficiency. Nat Genet. 2005;37:829-34.

55. Cunningham-Rundles $C$. Autoimmune manifestations in common variable immunodeficiency. J Clin Immunol. 2008;28(Suppl 1):S42-45.

56. Benson MJ, Dillon SR, Castigli E, Geha RS, Xu S, Lam KP, Noelle RJ. Cutting edge: the dependence of plasma cells and independence of memory B cells on BAFF and APRIL. J Immunol. 2008;180:3655-9.

57. Yang M, Hase H, Legarda-Addison D, Varughese L, Seed B, Ting AT. B cell maturation antigen, the receptor for a proliferation-inducing ligand and $B$ cell-activating factor of the TNF family, induces antigen presentation in B cells. J Immunol. 2005;175:2814-24.

58. Lee L, Draper B, Chaplin N, Philip B, Chin M, Galas-Filipowicz D, Onuoha S, Thomas S, Baldan V, Bughda R, et al. An APRIL-based chimeric antigen receptor for dual targeting of $\mathrm{BCMA}$ and $\mathrm{TACl}$ in multiple myeloma. Blood. 2018;131:746-58. 
59. Deng S, Yuan T, Cheng X, Jian R, Jiang J. B-lymphocyte-induced maturation protein 1 up-regulates the expression of B-cell maturation antigen in mouse plasma cells. Mol Biol Rep. 2010;37:3747-55.

60. Xu S, Lam KP. B-cell maturation protein, which binds the tumor necrosis factor family members BAFF and APRIL, is dispensable for humoral immune responses. Mol Cell Biol. 2001;21:4067-74.

61. Thompson JS, Schneider P, Kalled SL, Wang L, Lefevre EA, Cachero TG, MacKay F, Bixler SA, Zafari M, Liu ZY, et al. BAFF binds to the tumor necrosis factor receptor-like molecule $B$ cell maturation antigen and is important for maintaining the peripheral B cell population. J Exp Med. 2000;192:129-35.

62. Laabi Y, Gras MP, Brouet JC, Berger R, Larsen CJ, Tsapis A. The BCMA gene, preferentially expressed during $B$ lymphoid maturation, is bidirectionally transcribed. Nucleic Acids Res. 1994;22:1147-54.

63. Dogan A, Siegel D, Tran N, Fu A, Fowler J, Belani R, Landgren O. B-cell maturation antigen expression across hematologic cancers: a systematic literature review. Blood Cancer J. 2020;10:73.

64. Friedman KM, Garrett TE, Evans JW, Horton HM, Latimer HJ, Seidel SL, Horvath CJ, Morgan RA. Effective Targeting of Multiple B-Cell Maturation Antigen-Expressing Hematological Malignances by Anti-B-Cell Maturation Antigen Chimeric Antigen Receptor T Cells. Hum Gene Ther. 2018;29:585-601.

65. Bu DX, Singh R, Choi EE, Ruella M, Nunez-Cruz S, Mansfield KG, Bennett P, Barton N, Wu Q, Zhang J, et al. Pre-clinical validation of B cell maturation antigen (BCMA) as a target for $T$ cell immunotherapy of multiple myeloma. Oncotarget. 2018;9:25764-80.

66. Lee L, Bounds D, Paterson J, Herledan G, Sully K, Seestaller-Wehr LM, Fieles WE, Tunstead J, McCahon L, Germaschewski FM, et al. Evaluation of $B$ cell maturation antigen as a target for antibody drug conjugate mediated cytotoxicity in multiple myeloma. Br J Haematol. 2016;174:911-22.

67. Reghunathan R, Bi C, Liu SC, Loong KT, Chung TH, Huang G, Chng WJ. Clonogenic multiple myeloma cells have shared stemness signature associated with patient survival. Oncotarget. 2013:4:1230-40.

68. Chiu A, Xu W, He B, Dillon SR, Gross JA, Sievers E, Qiao X, Santini P, Hyjek $E$, Lee JW, et al. Hodgkin lymphoma cells express TACl and BCMA receptors and generate survival and proliferation signals in response to BAFF and APRIL. Blood. 2007;109:729-39.

69. Morgan GJ, Walker BA, Davies FE. The genetic architecture of multiple myeloma. Nat Rev Cancer. 2012;12:335-48.

70. Fowler JA, Mundy GR, Lwin ST, Edwards CM. Bone marrow stromal cells create a permissive microenvironment for myeloma development: a new stromal role for Wnt inhibitor Dkk1. Cancer Res. 2012;72:2183-9.

71. Hideshima T, Mitsiades C, Tonon G, Richardson PG, Anderson KC. Understanding multiple myeloma pathogenesis in the bone marrow to identify new therapeutic targets. Nat Rev Cancer. 2007;7:585-98.

72. Rennert P, Schneider P, Cachero TG, Thompson J, Trabach L, Hertig S, Holler N, Qian F, Mullen C, Strauch K, et al. A soluble form of B cell maturation antigen, a receptor for the tumor necrosis factor family member APRIL, inhibits tumor cell growth. J Exp Med. 2000;192:1677-84.

73. Alexaki VI, Notas G, Pelekanou V, Kampa M, Valkanou M, Theodoropoulos P, Stathopoulos EN, Tsapis A, Castanas E. Adipocytes as immune cells: differential expression of TWEAK, BAFF, and APRIL and their receptors (Fn14, BAFF-R, TACl, and BCMA) at different stages of normal and pathological adipose tissue development. J Immunol. 2009:183:5948-56.

74. Pelekanou V, Notas G, Kampa M, Tsentelierou E, Stathopoulos EN, Tsapis A, Castanas E. BAFF, APRIL, TWEAK, BCMA, TACI and Fn14 proteins are related to human glioma tumor grade: immunohistochemistry and public microarray data meta-analysis. PLoS ONE. 2013;8:e83250.

75. Avery DT, Kalled SL, Ellyard JI, Ambrose C, Bixler SA, Thien M, Brink R, Mackay F, Hodgkin PD, Tangye SG. BAFF selectively enhances the survival of plasmablasts generated from human memory B cells. J Clin Invest. 2003;112:286-97.

76. Milone MC, Fish JD, Carpenito C, Carroll RG, Binder GK, Teachey D, Samanta M, Lakhal M, Gloss B, Danet-Desnoyers G, et al. Chimeric receptors containing CD137 signal transduction domains mediate enhanced survival of T cells and increased antileukemic efficacy in vivo. Mol Ther. 2009:17:1453-64.

77. Chauhan D, Singh AV, Brahmandam M, Carrasco R, Bandi M, Hideshima T, Bianchi G, Podar K, Tai Y-T, Mitsiades C, et al. Functional interaction of plasmacytoid dendritic cells with multiple myeloma cells: a therapeutic target. Cancer Cell. 2009;16:309-23.

78. Tai YT, Mayes PA, Acharya C, Zhong MY, Cea M, Cagnetta A, Craigen J, Yates J, Gliddon L, Fieles W, et al. Novel anti-B-cell maturation antigen antibody-drug conjugate (GSK2857916) selectively induces killing of multiple myeloma. Blood. 2014;123:3128-38.

79. Pont MJ, Hill T, Cole GO, Abbott JJ, Kelliher J, Salter Al, Hudecek M, Comstock ML, Rajan A, Patel BKR, et al. $\gamma$-Secretase inhibition increases efficacy of BCMA-specific chimeric antigen receptor T cells in multiple myeloma. Blood. 2019;134:1585-97.

80. Laurent SA, Hoffmann FS, Kuhn PH, Cheng Q, Chu Y, Schmidt-Supprian M, Hauck SM, Schuh E, Krumbholz M, Rübsamen H, et al. $\gamma$-Secretase directly sheds the survival receptor BCMA from plasma cells. Nat Commun. 2015;6:7333.

81. Bellucci R, Alyea EP, Chiaretti S, Wu CJ, Zorn E, Weller E, Wu B, Canning C, Schlossman R, Munshi NC, et al. Graft-versus-tumor response in patients with multiple myeloma is associated with antibody response to BCMA, a plasma-cell membrane receptor. Blood. 2005;105:3945-50.

82. Vardanyan S, Meid K, Udd K, Wang J, Li M, Sanchez E, Wang C, Gillespie A, Spitzer M, Spektor T, et al. Serum Levels of B-Cell Maturation Antigen Are Elevated in Waldenström's Macroglobulinemia Patients and Correlate with Disease Status and Conventional M-Protein and IgM Levels. Blood. 2015;126:1778-1778.

83. Sanchez E, Li M, Kitto A, Li J, Wang CS, Kirk DT, Yellin O, Nichols CM, Dreyer MP, Ahles CP, et al. Serum B-cell maturation antigen is elevated in multiple myeloma and correlates with disease status and survival. $\mathrm{Br}$ J Haematol. 2012;158:727-38.

84. Sanchez E, Gillespie A, Tang G, Ferros M, Harutyunyan NM, Vardanyan S, Gottlieb J, Li M, Wang CS, Chen H, Berenson JR. Soluble B-Cell Maturation Antigen Mediates Tumor-Induced Immune Deficiency in Multiple Myeloma. Clin Cancer Res. 2016;22:3383-97.

85. Darce JR, Arendt BK, Chang SK, Jelinek DF. Divergent effects of BAFF on human memory B cell differentiation into Ig-secreting cells. J Immunol. 2007;178:5612-22.

86. von Bülow G-U, Bram RJ. NF-AT Activation Induced by a CAML-Interacting Member of the Tumor Necrosis Factor Receptor Superfamily. Science. 1997;278:138-41.

87. Thompson JS, Bixler SA, Qian F, Vora K, Scott ML, Cachero TG, Hession C, Schneider P, Sizing ID, Mullen C, et al. BAFF-R, a newly identified TNF receptor that specifically interacts with BAFF. Science. 2001;293:2108-11.

88. Yan M, Brady JR, Chan B, Lee WP, Hsu B, Harless S, Cancro M, Grewal IS, Dixit VM. Identification of a novel receptor for B lymphocyte stimulator that is mutated in a mouse strain with severe B cell deficiency. Curr Biol. 2001;11:1547-52.

89. Bischof D, Elsawa SF, Mantchev G, Yoon J, Michels GE, Nilson A, Sutor SL, Platt JL, Ansell SM, von Bulow G, Bram RJ. Selective activation of TACI by syndecan-2. Blood. 2006;107:3235-42.

90. Gorelik L, Cutler AH, Thill G, Miklasz SD, Shea DE, Ambrose C, Bixler SA, Su L, Scott ML, Kalled SL. Cutting edge: BAFF regulates CD21/35 and CD23 expression independent of its B cell survival function. J Immunol. 2004;172:762-6.

91. Reichlin A, Hu Y, Meffre E, Nagaoka H, Gong S, Kraus M, Rajewsky K, Nussenzweig MC. B cell development is arrested at the immature B cell stage in mice carrying a mutation in the cytoplasmic domain of immunoglobulin beta. J Exp Med. 2001;193:13-23.

92. Schiemann B, Gommerman JL, Vora K, Cachero TG, Shulga-Morskaya S, Dobles M, Frew E, Scott ML. An essential role for BAFF in the normal development of B cells through a BCMA-independent pathway. Science. 2001;293:2111-4.

93. Shulga-Morskaya S, Dobles M, Walsh ME, Ng LG, MacKay F, Rao SP, Kalled SL, Scott ML. B cell-activating factor belonging to the TNF family acts through separate receptors to support B cell survival and T cellindependent antibody formation. J Immunol. 2004;173:2331-41.

94. Seshasayee D, Valdez P, Yan M, Dixit VM, Tumas D, Grewal IS. Loss of TACI Causes Fatal Lymphoproliferation and Autoimmunity, Establishing TACI as an Inhibitory BLyS Receptor. Immunity. 2003;18:279-88.

95. Hatzoglou A, Roussel J, Bourgeade MF, Rogier E, Madry C, Inoue J, Devergne O, Tsapis A. TNF receptor family member BCMA (B cell maturation) associates with TNF receptor-associated factor (TRAF) 1, TRAF2, 
and TRAF3 and activates NF-kappa B, elk-1, c-Jun N-terminal kinase, and p38 mitogen-activated protein kinase. J Immunol. 2000;165:1322-30.

96. Bossen C, Schneider P. BAFF, APRIL and their receptors: structure, function and signaling. Semin Immunol. 2006;18:263-75.

97. Rickert R, Jellusova J: TNF and TNFR Family Members and B Cell Activation. Encyclopedia of Immunobiology 2016.

98. Patke A, Mecklenbräuker I, Erdjument-Bromage H, Tempst P, Tarakhovsky A. BAFF controls B cell metabolic fitness through a PKC betaand Akt-dependent mechanism. J Exp Med. 2006;203:2551-62.

99. Oeckinghaus A, Ghosh S. The NF-kappaB family of transcription factors and its regulation. Cold Spring Harb Perspect Biol. 2009;1:a000034

100. Senftleben U, Cao Y, Xiao G, Greten FR, Krähn G, Bonizzi G, Chen Y, Hu Y, Fong A, Sun SC, Karin M. Activation by IKKalpha of a second, evolutionary conserved NF-kappa B signaling pathway. Science. 2001;293:1495-9.

101. Ling L, Cao Z, Goeddel DV. NF-kappaB-inducing kinase activates IKK-alpha by phosphorylation of Ser-176. Proc Natl Acad Sci USA. 1998;95:3792-7.

102. Liao G, Zhang M, Harhaj EW, Sun SC. Regulation of the NF-kappaBinducing kinase by tumor necrosis factor receptor-associated factor 3-induced degradation. J Biol Chem. 2004;279:26243-50.

103. Vallabhapurapu S, Matsuzawa A, Zhang W, Tseng PH, Keats JJ, Wang H, Vignali DA, Bergsagel PL, Karin M. Nonredundant and complementary functions of TRAF2 and TRAF3 in a ubiquitination cascade that activates NIK-dependent alternative NF-kappaB signaling. Nat Immunol. 2008;9:1364-70.

104. Yamada T, Mitani T, Yorita K, Uchida D, Matsushima A, Iwamasa K, Fujita S, Matsumoto M. Abnormal immune function of hemopoietic cells from alymphoplasia (aly) mice, a natural strain with mutant NF-kappa B-inducing kinase. J Immunol. 2000;165:804-12.

105. Hatada EN, Do RK, Orlofsky A, Liou HC, Prystowsky M, MacLennan IC, Caamano J, Chen-Kiang S. NF-kappa B1 p50 is required for BLyS attenuation of apoptosis but dispensable for processing of NF-kappa B2 p100 to p52 in quiescent mature B cells. J Immunol. 2003;171:761-8.

106. Sommer K, Guo B, Pomerantz JL, Bandaranayake AD, Moreno-García ME, Ovechkina YL, Rawlings DJ. Phosphorylation of the CARMA1 linker controls NF-kappaB activation. Immunity. 2005;23:561-74.

107. Zarnegar B, Yamazaki S, He JQ, Cheng G. Control of canonical NFkappaB activation through the NIK-IKK complex pathway. Proc Natl Acad Sci USA. 2008;105:3503-8.

108. O'Mahony A, Lin X, Geleziunas R, Greene WC. Activation of the heterodimeric IkappaB kinase alpha (IKKalpha)-IKKbeta complex is directional: IKKalpha regulates IKKbeta under both basal and stimulated conditions. Mol Cell Biol. 2000;20:1170-8.

109. Rickert RC, Jellusova J, Miletic AV. Signaling by the tumor necrosis factor receptor superfamily in B-cell biology and disease. Immunol Rev. 2011;244:115-33.

110. Jellusova J, Miletic AV, Cato MH, Lin W-W, Hu Y, Bishop GA, Shlomchik $\mathrm{MJ}$, Rickert RC. Context-specific BAFF-R signaling by the NF-KB and PI3K pathways. Cell Rep. 2013;5:1022-35.

111. Woodland RT, Fox CJ, Schmidt MR, Hammerman PS, Opferman JT, Korsmeyer SJ, Hilbert DM, Thompson CB. Multiple signaling pathways promote B lymphocyte stimulator dependent B-cell growth and survival. Blood. 2008;111:750-60.

112. Fruman DA, Cantley LC. Phosphoinositide 3-kinase in immunological systems. Semin Immunol. 2002;14:7-18.

113. Leslie NR, Downes CP. PTEN: The down side of PI 3-kinase signalling. Cell Signal. 2002;14:285-95.

114. Henley T, Kovesdi D, Turner M. B-cell responses to B-cell activation factor of the TNF family (BAFF) are impaired in the absence of PI3K delta. Eur J Immunol. 2008;38:3543-8.

115. Khan WN. B cell receptor and BAFF receptor signaling regulation of $B$ cell homeostasis. J Immunol. 2009;183:3561-7.

116. Shinners NP, Carlesso G, Castro I, Hoek KL, Corn RA, Woodland RT, Scott ML, Wang D, Khan WN. Bruton's tyrosine kinase mediates NF-kappa B activation and $B$ cell survival by $B$ cell-activating factor receptor of the TNF-R family. J Immunol. 2007;179:3872-80.

117. Maurer U, Charvet C, Wagman AS, Dejardin E, Green DR. Glycogen synthase kinase-3 regulates mitochondrial outer membrane permeabilization and apoptosis by destabilization of MCL-1. Mol Cell. 2006:21:749-60
118. Brunet $\mathrm{A}$, Bonni A, Zigmond MJ, Lin MZ, Juo P, Hu LS, Anderson MJ, Arden KC, Blenis J, Greenberg ME. Akt promotes cell survival by phosphorylating and inhibiting a Forkhead transcription factor. Cell. 1999;96:857-68.

119. Dengler HS, Baracho GV, Omori SA, Bruckner S, Arden KC, Castrillon $\mathrm{DH}$, DePinho RA, Rickert RC. Distinct functions for the transcription factor Foxo1 at various stages of B cell differentiation. Nat Immunol. 2008;9:1388-98

120. You H, Pellegrini M, Tsuchihara K, Yamamoto K, Hacker G, Erlacher M, Villunger A, Mak TW. FOXO3a-dependent regulation of Puma in response to cytokine/growth factor withdrawal. J Exp Med. 2006;203:1657-63.

121. Dijkers PF, Medema RH, Lammers JW, Koenderman L, Coffer PJ. Expression of the pro-apoptotic $\mathrm{BCl}-2$ family member Bim is regulated by the forkhead transcription factor FKHR-L1. Curr Biol. 2000;10:1201-4.

122. Elgueta R, Benson MJ, de Vries VC, Wasiuk A, Guo Y, Noelle RJ. Molecular mechanism and function of CD40/CD40L engagement in the immune system. Immunol Rev. 2009;229:152-72.

123. Schwartz MA, Kolhatkar NS, Thouvenel C, Khim S, Rawlings DJ. CD4+ T cells and CD40 participate in selection and homeostasis of peripheral $B$ cells. J Immunol. 2014:193:3492-502.

124. Bishop GA, Hostager BS. The CD40-CD154 interaction in B cell-T cell liaisons. Cytokine Growth Factor Rev. 2003;14:297-309.

125. Erickson LD, Durell BG, Vogel LA, O'Connor BP, Cascalho M, Yasui T, Kikutani H, Noelle RJ. Short-circuiting long-lived humoral immunity by the heightened engagement of CD40. J Clin Investig. 2002;109:613-20.

126. Zarnegar B, He JQ, Oganesyan G, Hoffmann A, Baltimore D, Cheng G. Unique CD40-mediated biological program in $\mathrm{B}$ cell activation requires both type 1 and type 2 NF-kappaB activation pathways. Proc Natl Acad Sci U S A. 2004;101:8108-13.

127. Ren CL, Morio T, Fu SM, Geha RS. Signal transduction via CD40 involves activation of lyn kinase and phosphatidylinositol-3-kinase, and phosphorylation of phospholipase C gamma 2. J Exp Med. 1994;179:673-80.

128. Gallagher E, Enzler T, Matsuzawa A, Anzelon-Mills A, Otero D, Holzer R, Janssen E, Gao M, Karin M. Kinase MEKK1 is required for CD40-dependent activation of the kinases Jnk and p38, germinal center formation, $B$ cell proliferation and antibody production. Nat Immunol. 2007;8:57-63.

129. Leo E, Welsh K, Matsuzawa S, Zapata JM, Kitada S, Mitchell RS, Ely KR, Reed JC. Differential requirements for tumor necrosis factor receptor-associated factor family proteins in CD40-mediated induction of NF-kappaB and Jun N-terminal kinase activation. J Biol Chem. 1999;274:22414-22

130. Pullen SS, Miller HG, Everdeen DS, Dang TT, Crute JJ, Kehry MR. CD40tumor necrosis factor receptor-associated factor (TRAF) interactions: regulation of CD40 signaling through multiple TRAF binding sites and TRAF hetero-oligomerization. Biochemistry. 1998;37:11836-45.

131. Arcipowski KM, Bishop GA. Roles of the kinase TAK1 in TRAF6-dependent signaling by CD40 and its oncogenic viral mimic, LMP1. PLOS ONE. 2012;7:e42478.

132. Zhang B, Wang Z, Li T, Tsitsikov EN, Ding HF. NF-kappaB2 mutation targets TRAF1 to induce lymphomagenesis. Blood. 2007;1 10:743-51.

133. Hahne M, Kataoka T, Schröter M, Hofmann K, Irmler M, Bodmer JL, Schneider P, Bornand T, Holler N, French LE, et al. APRIL, a new ligand of the tumor necrosis factor family, stimulates tumor cell growth. J Exp Med. 1998;188:1185-90.

134. Alexopoulou AN, Multhaupt HA, Couchman JR. Syndecans in wound healing, inflammation and vascular biology. Int J Biochem Cell Biol. 2007:39:505-28.

135. Bolkun L, Lemancewicz D, Jablonska E, Kulczynska A, Bolkun-Skornicka U, Kloczko J, Dzieciol J. BAFF and APRIL as TNF superfamily molecules and angiogenesis parallel progression of human multiple myeloma. Ann Hematol. 2014;93:635-44.

136. Yu G, Boone T, Delaney J, Hawkins N, Kelley M, Ramakrishnan M McCabe S, Qiu WR, Kornuc M, Xia XZ, et al. APRIL and TALL-I and receptors BCMA and TACl: system for regulating humoral immunity. Nat Immunol. 2000;1:252-6.

137. Annunziata CM, Davis RE, Demchenko Y, Bellamy W, Gabrea A, Zhan F, Lenz G, Hanamura I, Wright G, Xiao W, et al. Frequent engagement of the classical and alternative NF-kappaB pathways by diverse genetic abnormalities in multiple myeloma. Cancer Cell. 2007;12:115-30.

138. Keats JJ, Fonseca R, Chesi M, Schop R, Baker A, Chng WJ, Van Wier S, Tiedemann R, Shi CX, Sebag M, et al. Promiscuous mutations activate 
the noncanonical NF-kappaB pathway in multiple myeloma. Cancer Cell. 2007;12:131-44.

139. Häcker $H$, Tseng PH, Karin M. Expanding TRAF function: TRAF3 as a trifaced immune regulator. Nat Rev Immunol. 2011;11:457-68.

140. Richardson PG, Mitsiades C, Hideshima T, Anderson KC. Bortezomib: proteasome inhibition as an effective anticancer therapy. Annu Rev Med. 2006;57:33-47.

141. Rodriguez-Abreu D, Bordoni A, Zucca E. Epidemiology of hematological malignancies. Ann Oncol. 2007;18(Suppl 1):i3-8.

142. Kyle RA, Gertz MA, Witzig TE, Lust JA, Lacy MQ, Dispenzieri A, Fonseca R, Rajkumar SV, Offord JR, Larson DR, et al. Review of 1027 patients with newly diagnosed multiple myeloma. Mayo Clin Proc. 2003;78:21-33.

143. Kuehl WM, Bergsagel PL. Molecular pathogenesis of multiple myeloma and its premalignant precursor. J Clin Invest. 2012;122:3456-63.

144. Manier S, Salem KZ, Park J, Landau DA, Getz G, Ghobrial IM. Genomic complexity of multiple myeloma and its clinical implications. Nat Rev Clin Oncol. 2017;14:100-13.

145. Palumbo A, Anderson K. Multiple myeloma. N Engl J Med. 2011;364:1046-60.

146. Rosiñol L, Oriol A, Teruel Al, Hernández D, López-Jiménez J, de la Rubia J, Granell M, Besalduch J, Palomera L, González Y, et al. Superiority of bortezomib, thalidomide, and dexamethasone (VTD) as induction pretransplantation therapy in multiple myeloma: a randomized phase 3 PETHEMA/GEM study. Blood. 2012;120:1589-96.

147. Laubach JP, Voorhees PM, Hassoun H, Jakubowiak A, Lonial S, Richardson PG. Current strategies for treatment of relapsed/refractory multiple myeloma. Expert Rev Hematol. 2014;7:97-111.

148. Richardson PG, Sonneveld P, Schuster MW, Irwin D, Stadtmauer EA, Facon T, Harousseau JL, Ben-Yehuda D, Lonial S, Goldschmidt H, et al. Bortezomib or high-dose dexamethasone for relapsed multiple myeloma. N Engl J Med. 2005;352:2487-98.

149. Richardson PG, Jagannath S, Moreau P, Jakubowiak AJ, Raab MS, Facon T, Vij R, White D, Reece DE, Benboubker L, et al. Elotuzumab in combination with lenalidomide and dexamethasone in patients with relapsed multiple myeloma: final phase 2 results from the randomised, open-label, phase $1 \mathrm{~b}-2$ dose-escalation study. Lancet Haematol. 2015;2:e516-527.

150. Deckert J, Wetzel MC, Bartle LM, Skaletskaya A, Goldmacher VS, Vallée F, Zhou-Liu Q, Ferrari P, PouzieuX S, Lahoute C, et al. SAR650984, a novel humanized CD38-targeting antibody, demonstrates potent antitumor activity in models of multiple myeloma and other CD38+ hematologic malignancies. Clin Cancer Res. 2014;20:4574-83.

151. Kinneer K, Meekin J, Tiberghien AC: SLC46A3 as a Potential Predictive Biomarker for Antibody-Drug Conjugates Bearing Noncleavable Linked Maytansinoid and Pyrrolobenzodiazepine Warheads. 2018, 24:6570-6582.

152. Alley SC, Okeley NM, Senter PD. Antibody-drug conjugates: targeted drug delivery for cancer. Curr Opin Chem Biol. 2010;14:529-37.

153. de Oca RMAA, Vitali N, Bhattacharya S, Blackwell C, Patel K, SeestallerWehr L, Kaczynski H, Shi H, Dobrzynski E, Obert L. Belantamab Mafodotin (GSK2857916) Drives Immunogenic Cell Death and Immune-mediated Antitumor Responses In Vivo. Mol Cancer Ther. 2021:20(10):1941-55.

154. Trudel SLN, Popat R, Voorhees PM, Reeves B, Libby EN, Richardson PG, Anderson LD Jr, Sutherland HJ, Yong K, Hoos A. Targeting B-cell maturation antigen with GSK2857916 antibody-drug conjugate in relapsed or refractory multiple myeloma (BMA117159): a dose escalation and expansion phase 1 trial. Lancet Oncol. 2018;19(12):1641-53.

155. Maus MV, Grupp SA, Porter DL, June CH. Antibody-modified T cells: CARs take the front seat for hematologic malignancies. Blood. 2014;123:2625-35.

156. Dudley ME, Wunderlich JR, Shelton TE, Even J, Rosenberg SA. Generation of tumor-infiltrating lymphocyte cultures for use in adoptive transfer therapy for melanoma patients. J Immunother. 2003:26:332-42.

157. Davila ML, Sauter C, Brentjens R. CD19-Targeted T Cells for Hematologic Malignancies: Clinical Experience to Date. Cancer J. 2015;21:470-4.

158. Sadelain M, Rivière I, Brentjens R. Targeting tumours with genetically enhanced T lymphocytes. Nat Rev Cancer. 2003;3:35-45.

159. Irving BA, Weiss A. The cytoplasmic domain of the T cell receptor zeta chain is sufficient to couple to receptor-associated signal transduction pathways. Cell. 1991;64:891-901.
160. Abate-Daga D, Davila ML. CAR models: next-generation CAR modifications for enhanced T-cell function. Mol Ther Oncolytics. 2016;3:16014.

161. Rossjohn J, Gras S, Miles JJ, Turner SJ, Godfrey DI, McCluskey J. T cell antigen receptor recognition of antigen-presenting molecules. Annu Rev Immunol. 2015;33:169-200.

162. Sharpe AH, Freeman GJ. The B7-CD28 superfamily. Nat Rev Immunol. 2002;2:116-26

163. Maher J, Brentjens RJ, Gunset G, Rivière I, Sadelain M. Human T-lymphocyte cytotoxicity and proliferation directed by a single chimeric TCRzeta /CD28 receptor. Nat Biotechnol. 2002;20:70-5.

164. Hombach A, Wieczarkowiecz A, Marquardt T, Heuser C, Usai L, Pohl C, Seliger B, Abken $\mathrm{H}$. Tumor-specific T cell activation by recombinant immunoreceptors: $\mathrm{CD} 3$ zeta signaling and CD28 costimulation are simultaneously required for efficient IL-2 secretion and can be integrated into one combined CD28/CD3 zeta signaling receptor molecule. J Immunol. 2001;167:6123-31.

165. Imai C, Mihara K, Andreansky M, Nicholson IC, Pui CH, Geiger TL, Campana D. Chimeric receptors with 4-1BB signaling capacity provoke potent cytotoxicity against acute lymphoblastic leukemia. Leukemia. 2004:18:676-84.

166. Song DG, Ye Q, Poussin M, Harms GM, Figini M, Powell DJ Jr. CD27 costimulation augments the survival and antitumor activity of redirected human T cells in vivo. Blood. 2012;119:696-706.

167. Hombach AA, Abken $\mathrm{H}$. Of chimeric antigen receptors and antibodies: OX40 and 41BB costimulation sharpen up T cell-based immunotherapy of cancer. Immunotherapy. 2013;5:677-81.

168. Hombach AA, Heiders J, Foppe M, Chmielewski M, Abken H. OX40 costimulation by a chimeric antigen receptor abrogates CD28 and IL-2 induced IL-10 secretion by redirected CD4(+) T cells. Oncoimmunology. 2012;1:458-66.

169. Chmielewski M, Abken H. TRUCKs: the fourth generation of CARs. Expert Opin Biol Ther. 2015;15:1145-54.

170. Hurton LV, Singh H, Najjar AM, Switzer KC, Mi T, Maiti S, Olivares S, Rabinovich B, Huls H, Forget MA, et al. Tethered IL-15 augments antitumor activity and promotes a stem-cell memory subset in tumor-specific $T$ cells. Proc Natl Acad Sci U S A. 2016;113:E7788-e7797.

171. Kim DW, Cho J-Y. Recent Advances in Allogeneic CAR-T Cells. Biomolecules. 2020;10:263.

172. Zhao L, Cao YJ. Engineered T Cell Therapy for Cancer in the Clinic. Front Immunol. 2019;10:2250-2250.

173. Wang Z, Wu Z, Liu Y, Han W. New development in CAR-T cell therapy. J Hematol Oncol. 2017:10:53.

174. Moreau P, Sonneveld P, Boccadoro M, Cook G, Mateos MV, Nahi H, Goldschmidt H, Dimopoulos MA, Lucio P, Bladé J, et al. Chimeric antigen receptor T-cell therapy for multiple myeloma: a consensus statement from The European Myeloma Network. Haematologica. 2019:104:2358-60.

175. Danhof S, Hudecek M, Smith EL. CARs and other T cell therapies for MM: The clinical experience. Best Pract Res Clin Haematol. 2018;31:147-57.

176. Mikkilineni L, Kochenderfer JN. Chimeric antigen receptor T-cell therapies for multiple myeloma. Blood. 2017;130:2594-602.

177. Grupp SA, Kalos M, Barrett D, Aplenc R, Porter DL, Rheingold SR, Teachey DT, Chew A, Hauck B, Wright JF, et al. Chimeric antigen receptor-modified $\mathrm{T}$ cells for acute lymphoid leukemia. N Engl J Med. 2013:368:1509-18.

178. Neelapu SS, Locke FL, Bartlett NL, Lekakis LJ, Miklos DB, Jacobson CA, Braunschweig I, Oluwole OO, Siddiqi T, Lin Y, et al. Axicabtagene Ciloleucel CAR T-Cell Therapy in Refractory Large B-Cell Lymphoma. N Engl J Med. 2017:377:2531-44.

179. Posey AD Jr, Schwab RD, Boesteanu AC, Steentoft C, Mandel U, Engels B, Stone JD, Madsen TD, Schreiber K, Haines KM, et al. Engineered CART Cells Targeting the Cancer-Associated Tn-Glycoform of the Membrane Mucin MUC1 Control Adenocarcinoma. Immunity. 2016;44:1444-54.

180. Hosen N, Matsunaga Y, Hasegawa K, Matsuno H, Nakamura Y, Makita M, Watanabe K, Yoshida M, Satoh K, Morimoto S, et al. The activated conformation of integrin $\beta(7)$ is a novel multiple myeloma-specific target for CART cell therapy. Nat Med. 2017;23:1436-43.

181. Brudno JN, Maric I, Hartman SD, Rose JJ, Wang M, Lam N, Stetler-Stevenson M, Salem D, Yuan C, Pavletic S, et al. T cells genetically modified to express an anti-B-cell maturation antigen chimeric antigen receptor 
cause remissions of poor-prognosis relapsed multiple myeloma. J Clin Oncol. 2018;36:2267-80.

182. Xu J, Chen LJ, Yang SS, Sun Y, Wu W, Liu YF, Xu J, Zhuang Y, Zhang W, Weng $X Q$, et al. Exploratory trial of a biepitopic CAR T-targeting B cell maturation antigen in relapsed/refractory multiple myeloma. Proc Natl Acad Sci USA. 2019;116:9543-51.

\section{Publisher's Note}

Springer Nature remains neutral with regard to jurisdictional claims in published maps and institutional affiliations.

- fast, convenient online submission

- thorough peer review by experienced researchers in your field

- rapid publication on acceptance

- support for research data, including large and complex data types

- gold Open Access which fosters wider collaboration and increased citations

- maximum visibility for your research: over $100 \mathrm{M}$ website views per year

At $\mathrm{BMC}$, research is always in progress.

Learn more biomedcentral.com/submissions 